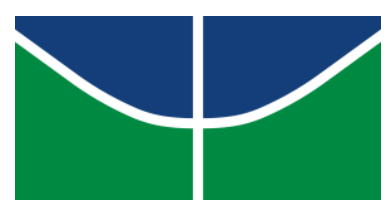

UNIVERSIDADE DE BRASÍLIA

INSTITUTO DE CIÊNCIAS HUMANAS

DEPARTAMENTO DE FILOSOFIA

\title{
O MECANISMO CINEMATOGRÁFICO DO PENSAMENTO DE HENRI BERGSON
}

Matheus Garcia Manfredini

Brasília

2017 


\title{
O MECANISMO CINEMATOGRÁFICO DO PENSAMENTO DE HENRI BERGSON
}

\author{
Trabalho de conclusão de curso em \\ graduação em Filosofia pela \\ Universidade de Brasília como requisito à \\ obtenção de Título de licenciado e \\ bacharel em Filosofia.
}

Orientador: Prof. Dr. Herivelto Souza

Brasília 


\section{Resumo}

O presente trabalho visa apresentar o mecanismo cinematográfico do pensamento de Henri Bergson, fonte dos falsos problemas que permeiam a teoria do conhecimento na filosofia. Para o filósofo francês uma teoria do conhecimento deve ser erigida sobre uma teoria da vida, dado que na busca genética da origem da inteligência pode-se determinar seu objeto de conhecimento, seu limite na apreensão da realidade, e a consequente construção de uma metafísica positiva, que mira o absoluto e a reabsorção do humano no todo. O cinematógrafo, enquanto mecanismo que cria o movimento a partir da justaposição de fotografias, opera de maneira semelhante à inteligência, que concebe o devir como a reunião de imobilidades. Esse mecanismo se constitui por uma origem empírica e pragmática fundada na necessidade de sobrevivência do organismo perante o meio, e é a fonte da própria materialidade do pensamento conceitual. Essa faculdade de conhecer é limitada aos fenômenos físicos, e o vivente escapa seu escopo. Para reivindicar a possibilidade do conhecimento Absoluto se torna imperativo para Bergson a defesa e indicação de um outro conhecimento possível, a partir de outra faculdade que não a inteligência, dirigida no sentido do instinto, porém desinteressada do âmbito pragmático. A filosofia da vida de Bergson nos fornecerá a chave para compreender as limitações da inteligência e a necessidade de se construir uma metafísica que almeja não a mera sobrevivência, mas a própria felicidade, possível no encontro da parte com o todo e do orgânico com o inorgânico.

Palavras-chave: Bergson. Metafísica. Intuição. Teoria do conhecimento. 


\section{Abstract}

The aim of the this work is to present the cinematographic mechanism of the thought of Henri Bergson as the source of the false problems that permeate the theory of knowledge in philosopy. For Bergson a theory of knowledge must be establish upon a theory of life, since it is in the genetic search of the origin of intelligence that one can determine its object of knowledge, its limit in the apprehension of the reality and then, a consequent construction of a positive metaphysics, aiming at the absolute and the reabsorption of the human in the whole. The cinematograph, as a mechanism that creates movement from the juxtaposition of photographs, works like the inteligence, which conceives the becoming as a set of immobilitys. This mechanism of the inteligence consists of an empirical and pragmatic origin based on the need for survival of the organism in the environment and is the source of the very materiality of conceptual thinking. This faculty of knowing is limited to physical phenomena, and the living escapes its scope. For the possibility of Absolute knowledge becomes imperative for Bergson the defense and indication of another faculty that is not intelligence, that operates from another outlook, directed towards the instinct, but desinterested of the pragmatism of biological necessities. The philosophy of Bergson give us the key to understand the limitations of the inteligence and the necessity to build a positive metafisics that seeks not just to ensure the simple survival, but the very happiness, only possible in the meeting of the part with the whole and the organic with the inorganic.

Key-words: Bergson. Metaphysics. Intuition. Theory of Knowledge. 


\section{Sumário}

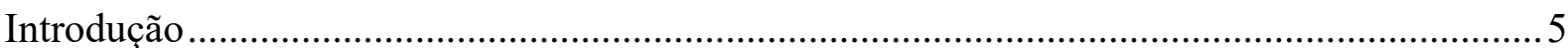

Capítulo 1 - A inteligência sob uma perspectiva evolutiva..................................................... 10

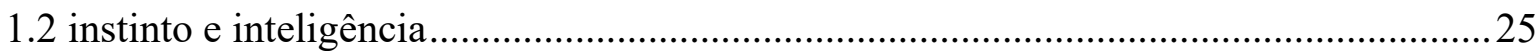

Capítulo 2 - As duas ordens e a superação da inteligência ......................................................30

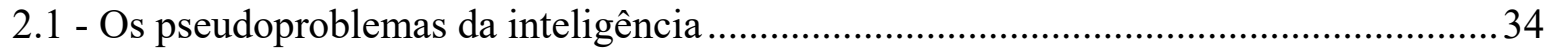

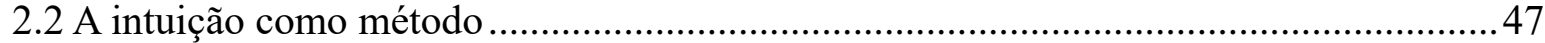

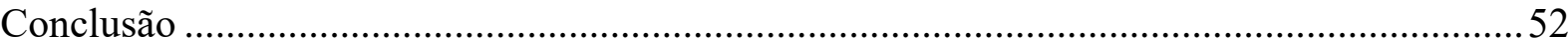

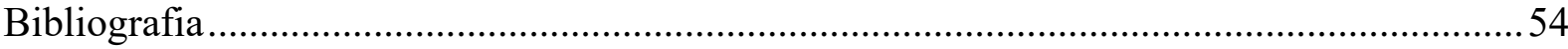




\section{Introdução}

A filosofia bergsoniana é uma filosofia esteticamente atrativa. Atrai pelo tema e pela força das imagens, enriquecidas pelo estilo do autor, que utiliza seu conhecimento científico e literário para insinuar movimentos inexprimíveis, na medida que transbordam a materialidade das palavras: movimentos da duração psicológica, dimensão que possui um estatuto ontológico na filosofia de Bergson. A linguagem fixa significados em conceitos e pretende estabilizar o movimento, que está sujeito todo fenômeno físico, químico e consciente. As coisas estabilizadas em estados como palavras constituem um conhecimento retrospectivo baseado na repetição e semelhança e criando sistemas fechados. Falar em tendências e em processo requer o uso de metáforas, porque a metáfora indica uma direção, um movimento interior e íntimo à imagem representada, mas que não a limita em uma forma ou prediz um efeito consequente. Toda tendência carrega uma ambiguidade conceitual, dado que transmite a ideia fluida de uma transição, de uma direção cambiante e não determinada. A essência da linguagem é supor que tudo é dado, isto é, implicada uma causa, segue-se um efeito, e que $A=A$. A igualdade e a repetição geram a generalização, cristalizada em palavras pela inteligência e com tendência natural a pensar em termos de gêneros e leis. A precisão da linguagem acompanha o grau de desenvolvimento e complexidade do cérebro dos vertebrados, culminando no cérebro humano com precisão geométrica e inclinação a refletir e projetar no mundo a forma mecanicista e finalista com que interpreta o devir. O intelecto se desenvolveu imitando a materialidade das coisas, e se caracteriza por uma natural inaptidão para compreender o vivente, enquanto ordem que escapa à analise mecanicista e finalista da inteligência.

Toda palavra tende a estabilizar um devir, como uma fotografia. E o cinema, como um mecanismo que a partir de fotografias gera a ilusão do movimento, se assemelha com o processo da inteligência, que a partir da linguagem cristalizada em significados estáveis gera a ilusão da sucessão a partir da justaposição e organização das palavras. Bergson chama a atenção para a diferença entre a sucessão e a justaposição, pois a sucessão orbita na direção do tempo, enquanto a justaposição na direção do espaço. O conceito da linguagem é preso em torno da ideia de espaço, e mesmo quando o sujeito pensa no tempo, se exprime como em uma quarta dimensão do espaço, isto é, não concede ao tempo uma realidade absoluta, mas o concebe como circunscrito ao deslocamento dos corpos. Pensamos em termos de mais e de 
menos e impregnamos nossa percepção do devir com as mesmas ferramentas usadas para a interpretação da materialidade. Ao se exprimir em conceitos perde-se a duração como consciência coextensiva à vida. Duração consciente e sucessão são utilizadas aqui como sinônimos, apreensíveis apenas por um conhecimento intuitivo do real.

Conceitos como unidade e multiplicidade são aplicáveis à matéria inerte, mas no domínio do psicológico vemos uma multiplicidade una e uma unidade múltipla, imagem contraditória incompreensível para a inteligência. A metáfora seria então a única ferramenta para se transmitir esse domínio espiritual, tanto na percepção da mudança dos estados conscientes quanto na multiplicidade contínua da vida. Essa sucessão do vivente é transmitida pela imagem movente, pela ambiguidade de significado própria da linguagem metafórica. A metáfora visa a transmissão de uma imagem que segue a ontologia da subjetividade do sujeito, e que subjaz nas formas viventes tanto quanto nas forças materiais como um princípio psicológico que atravessa a ambas. A vida é um fenômeno misterioso, causa de encantamento e espanto tanto quando analisada pela inteligência, através da conceitualização e da matemática com a crescente complexificação das suas operações, quanto encarada através da intuição pelos sentidos em uma presença imediata e não conceitual e que visa o absoluto, isto é, situa-se na esfera da multiplicidade contínua de interpenetração, onde tudo reage com tudo.

O virtual é um conceito fundamental na obra de Bergson, presente como a tendência que movimenta a evolução, e visível no processo de atualização do impulso vital. O atual é um devir que retorna ao virtual como memória gerando pressão na ação do organismo vivente, e atualizando novamente o virtual enquanto criação de novidade. Bergson nos fala de realidades superiores e inferiores a nós, ambas presentes em uma consciência que as atravessa, sensível nas plantas, no instinto dos insetos e na inteligência humana. O virtual enquanto multiplicidade contínua só pode ser concebido a partir de uma coincidência com a realidade de forma imediata; a mediação é realizada pela materialidade da palavra e pela lógica, e impossibilitam a intuição do absoluto. A coincidência como forma de conhecimento é uma generalização espiritual, que se distancia da generalidade empírica. Essa forma desinteressada de generalizar busca tocar o absoluto, mas é do corpo e da matéria que se eleva para a intuição, e não renega o corpo como a fonte das ilusões da razão, como procede Descartes e a tradição filosófica moderna. Essa intuição holística do absoluto carrega algo do instinto, a forma sui generis de conhecimento por simpatia que anima a ação dos insetos, porém distinta enquanto mantém um distanciamento 
da materialidade das coisas, distanciamento que falta ao instinto, identificado com o objeto a ponto de não reconhecer a si próprio como sujeito. A intuição é não conceitual, e se furta à palavra, mas por reintegrar a inteligência na duração movente realiza uma coincidência entre a objetividade das coisas e a subjetividade do intelecto. A palavra, cristalizada em um esforço intelectual para apreender a materialidade perde nesse processo aquilo que é qualitativo, isto é, sua própria tendência a variar. As metáforas devem ser compreendidas na obra bergsoniana como uma indicação de direção, e não a delimitação precisa de uma imagem estática.

A intuição como uma coincidência com o absoluto enquanto movimento, manifesta-se pelo esforço da vida a um observador imediato que não julga nem interpreta conceitualmente a realidade. O homem vê as coisas elementarmente como em um filme cinematográfico. Ilude-se que o movimento que concebe e imagina é representável pelo verbo, como a categoria linguística própria para a imagem do deslocamento e da mudança. A inteligência no bergsonismo é interpretada como um conhecimento negativo, pois acompanha a matéria em seu movimento descendente, isto é, que tende à inércia. O conhecimento positivo seria aquele que procura as articulações do real, no ponto onde tendências se potencializam, neutralizam e se diferenciam, como no choque de ondas. As articulações do real é a dimensão onde o espiritual encontra o material, dimensão de uma consciência coextensiva à vida e de um princípio psicológico parentado à própria materialidade. Impulso psicológico que se opõe à atração da matéria, num esforço ascendente contra a negatividade das coisas inertes. Essas articulações só podem ser observadas em uma virada da experiência, isto é, quando a ação se torna desinteressada, quando o ato especulativo abdica das ferramentas conceituais da inteligência e quando a atenção é absorvida no presente, sem memórias nem projeções futuras.

O movimento do real é fonte de dois conhecimentos distintos, com alcances diferentes no esforço de compreender e encarar a vida: pela inteligência ou pela intuição. A matéria é fonte da inteligência, e o vivente da intuição. A vida se constitui como objeto que possibilita despertar a intuição no observador, pois experienciamos o inexprimível quando observamos a riqueza e diversidade nas formas das espécies e no ininterrupto desenrolar de nossa própria vida mental. Segundo Bergson, uma teoria do conhecimento deve ser acompanhada por uma teoria da vida, e esse é objetivo do bergsonismo, erigir uma teoria do conhecimento a partir de uma consciência coextensiva ao fenômeno vital. A evolução da vida é em si tema de ricas possibilidades imagéticas e metáforas, utilizadas por Bergson para significar e 
enriquecer com esse movimento indiviso e geológico à nossa própria ligeira existência individual.

Segundo Bergson, é através da expressão artística que se torna possível a transmissibilidade desse conhecimento que ultrapassa a estrutura linguística da inteligência, e nesse sentido o trabalho de Bergson se presta à tarefa de propor uma superação da condição humana, similarmente a Nietzsche, quando reivindica um super-homem. A condição humana é determinada pelos condicionamentos da vida mental, condicionamentos construídos lentamente na evolução da vida, formadores de hábitos inconscientes sedimentados e enraizados profundamente em nossas mentes como tendências de abordar e manipular a matéria, e que progressivamente, enquanto a inteligência se especializa e se complexifica em técnica, se distancia da vida e da possibilidade de compreensão do fenômeno psicológico. As metáforas e a arte desempenham um papel preponderante no método bergsoniano enquanto enriquecem o espírito com a apreensão do devir, apreensão que escapa a linguagem da ciência positiva e do senso comum. Porém o cinema, como a mais popular das artes na contemporaneidade, carregada de metáforas por servir-se tanto do som quanto da imagem, foi escolhida por Bergson para ilustrar os mais antigos hábitos do entendimento, sede de falsos problemas e ilusões que permearam e macularam a história da filosofia e da ciência moderna sobre o fenômeno vital.

O presente trabalho visa apresentar a gênese ideal da inteligência a partir do evolucionismo espiritualista de Bergson, e o estudo genético desta evolução irá resultar na edificação da origem das ilusões do entendimento, apresentando o método intuitivo desenvolvido por Bergson e sua pretensão a erigir uma metafísica positiva, visando a superação da condição humana. Todo esse estudo visa perscrutar a consciência e a essência psicológica do fenômeno vital que Bergson busca estabelecer como fundamento gerador da totalidade. Compreender a consciência é fundamental para nos situarmos no tempo em que estamos imersos; e o tempo da inteligência, aquele em que operam os pensamentos conceituais, é um tempo cronológico, artificialmente concebido pelo intelecto. Mas além do tempo dos conceitos e do relógio, existe um tempo que incide nos intervalos, no vazio semântico entre as extremidades significadas pelas palavras ou números, intervalo onde incide o tempo qualitativo da duração, conceito fundamental na metafísica bergsoniana. A complexidade do texto de Bergson é crescente com a amplidão que esta intuição fundamental do tempo psicológico toma no sentido de abarcar todo o real em direção ao Absoluto. De empirista que dialoga frente a frente com a ciência de sua época, a 
um metafísico que busca erigir a base para um espiritualismo original, Bergson é um autor que nos ajuda a significar a nossa própria consciência.

O trabalho foi dividido em dois capítulos, com um subcapítulo no primeiro, e dois no segundo. O primeiro capítulo visa situar o bergsonismo no debate evolutivo, isto é, apresentar suas críticas as teorias científicas e filosóficas que teorizam sobre o fenômeno vital enquanto evolução. Nessa etapa acompanhamos o argumento bersgoniano em apresentar as duas vestimentas que nosso entendimento dispõe para pensar o real e consequentemente a vida: o mecanismo e a finalidade. $O$ primeiro, fundamento dos métodos científicos e presente no cartesianismo dos filósofos modernos, e o segundo, característica do pensamento clássico e religioso, enraizado no senso comum. Após apresentar o evolucionismo bergsoniano na primeira sessão do primeiro capítulo passaremos para uma segunda sessão, onde a discussão irá se basear nas linhas de evolução divergentes, centralizando a atenção nos vertebrados e o desenvolvimento do sistema nervoso, com a distinção entre instinto e inteligência. Essa sessão é fundamental para compreendermos a função do intelecto, tema do segundo capítulo.

No segundo capítulo iremos apresentar as duas ordens distintas que compõe a realidade no universo bergsoniano: a ordem geométrica da matéria e a ordem voluntária ou "querida" do impulso vital. Essa distinção será necessária para fundamentar a ontologia da duração, onde se coloca a origem psicológica do movimento de distensão da matéria no espaço e da tensão do impulso vital no tempo. Nesse momento o dualismo bergsoniano dá lugar a um monismo, onde a duração se coloca como fundamento do real. Estabelecida as duas ordens, a próxima subseção será destinada a apresentar as ilusões da inteligência e os pseudoproblemas dela resultantes, o que já implica uma exposição da intuição como método filosófico.

Por fim iremos delinear a intuição, como alternativa para o mecanismo cinematográfico da inteligência e como uma superação da condição humana, mirando outra humanidade possível. A conclusão do estudo irá trazer a questão cinematográfica para a atualidade e problematizar a metáfora do "mecanismo cinematográfico", dado que o cinema é uma arte poderosa para transmitir a intuição do movimento. 


\section{Capítulo 1 - A inteligência sob uma perspectiva evolutiva}

Procuramos unicamente saber qual o sentido exato que a nossa consciência dá à palavra "existir", e achamos que, para um ser consciente, existir consiste em mudar; mudar em amadurecer; amadurecer em se criar indefinidamente. Poderá dizer-se o mesmo da existência em geral? (BERGSON, 2010, p. 22)

No início do primeiro capítulo do livro A Evolução Criadora, intitulado "Sobre a evolução da vida - Mecanismo e Finalidade" Bergson nos convida a refletir sobre o conceito de existência, e com isso evidencia sua concepção de consciência como um fluir contínuo de percepções com qualidades diferentes que não suportam nossa atribuição quantificável de graus que diferenciariam as sensações entre si. É por conceber graus na sensação que somos levados a compará-las, e por compará-las conduzimo-nos ao erro, pois para Bergson, em cada estado da consciência estamos em um lugar novo e imprevisível, nunca antes experimentado. Em seus trabalhos anteriores, Bergson apresentou os dados imediatos da consciência como mistos de duração e espaço, consistindo a consciência justamente no vaguear entre os mistos, isto é, as percepções são como um amálgama de dois âmbitos opostos unificados na representação presente. A simples percepção imediata é já a união da memória que acompanha o organismo com a materialidade que o estimula, e depurar a percepção livrando-a do passado que a condiciona é um dispendioso esforço intelectual. Cabe à filosofia o papel de desenredar esses mistos da consciência, separando aquilo que pertence ao âmbito da duração (ou da memória pura) daquilo que pertence ao espaço, pois é pela ignorância dos mistos que problemas insolúveis se apresentam para a teoria do conhecimento, e que levaram ao erro todos os sistemas filosóficos formulados anteriormente.

A consciência é volátil e impassível de ser medida; ela se constitui antes por um fluxo que por uma coisa. Essa afirmação é sustentada pela constatação que as memórias, mesmo as "inúteis", nunca se perdem e permanecem presentes para auxiliar o indivíduo a desempenhar suas atividades no mundo circundante. $O$ famoso fragmento heraclitiano de que "Nos mesmos rios entramos e não entramos, somos e não somos" (HERÁCLITO, 2012, p. 141) cabe ao bergsonismo, aonde nunca repetimos uma sensação, nunca sentimos o presente de forma igual à maneira experimentada no passado. O presente rói o porvir e cresce enquanto avança, isto é, a ação livre é caracterizada por uma contração de toda nossa memória na escolha de uma ação presente, e a cada momento o material com que o ser vivo dispõe para agir num futuro eminente é enriquecido por todo seu passado. Para Bergson a inteligência 
humana evoluiu com o propósito de auxiliar o organismo a agir, e não é um luxo tardio que se desenvolveu independente das necessidades vitais. Porém a inteligência ultrapassa a função pragmática de adaptação ao meio, e nossa memória nos serve em leque para acessar lembranças com propósitos outros que a mera inserção útil no momento presente.

Bergson quer uma filosofia que leve em conta a criação e a novidade no tempo, pois o ser humano se caracteriza precisamente pela ação livre, onde todo o passado concorre para assegurar ao indivíduo a ação apropriada, porém de maneira fluida, como em uma dança, com resultados que se encontravam em potência no passado, mas onde o futuro jazia imprevisível, e onde o possível se configurou a partir do real, e não antes dele. A duração própria da consciência é, portanto, um misto das vibrações provenientes do mundo circundante, emitidas pela matéria e captadas pelos sentidos, vibrações estas reconhecidas e associadas a uma identidade e uma causalidade, apreendidas como repetição e inteligíveis como gêneros de semelhanças. Outro, o âmbito propriamente espiritual, aquele da memória, que capta essas vibrações e mistura a elas experiências passadas, com juízos e sentimentos formados a partir das disposições do indivíduo. Duração consciente que por definição a inteligência ignora, pois a inteligência se distende sobre certa superficialidade do real, isto é, na dimensão onde se desenrolam os fenômenos físicos apreensíveis pelos sentidos. Porém o que o tempo possui de perene é a própria diferença que mantém com o passado que carrega em germe e que atualiza no espaço em uma nova forma. A inteligência tende a recortar instantes e perder de vista o fio que conecta esses estados entre si. Combinamos movimentos, de uma causa ligamos um efeito, e de um afeito associamos uma mesma causa, tendo sempre em vista um objetivo a ser alcançado. Somos geômetras e artífices por necessidades de adaptação ao meio ambiente. A vida e seu movimento, para Bergson, nos dá o material para compreender a inteligência humana e consequentemente a crítica de suas insuficiências, porque o movimento evolutivo ultrapassa a compreensão inteligente, demandando um esforço que puxa e arrasta a inteligência a um raciocínio oposto a seu movimento habitual.

Após a definição de consciência no início do livro, Bergson parte para uma analogia da vida e o que ela tem de evolutivo e da consciência no que ela tem de temporal, pois para Bergson a teoria do conhecimento e a teoria da vida são inseparáveis, isto é, devemos buscar nos elementos da evolução a razão de ser da inteligência e os sinais da consciência dos seres vivos. Neste sentido podemos dizer que a crítica de Bergson é genética, pois busca os fundamentos dos processos 
teóricos da inteligência na esfera pragmática da necessidade de sobrevivência dos seres perante o meio. "É preciso que essas duas pesquisas, teoria do conhecimento e teoria da vida, se encontrem e que, por meio de um processo circular, impulsionem uma à outra indefinidamente" (BERGSON, 2010, p. 12). O objetivo do presente estudo é apresentar o método cinematográfico de Bergson, e para tanto precisamos ter em mente que para o filósofo existe um distanciamento entre a vida e a nossa forma habitual de conhecer.

Friederic Worms irá ressaltar na obra bergsoniana diversos dualismos, ressaltando intrinsecamente em toda a obra uma divisão entre dois sentidos da vida. Por um lado, a matéria é pensada como uma distensão, um relaxamento que se dirige para baixo, rumo à inércia. A vida, por outro lado, é um esforço, uma tensão finita que se dirige para cima, contra a matéria, a partir de um feixe. Uma dicotomia angular para compreender o evolucionismo de Bergson e todas as dualidades que surgem em sua obra é a de duração e espaço. A duração como conceito filosófico é heterogeneidade contínua, diferença em si mesma e criação incessante de novidade, e o espaço é homogeneidade descontínua, e seu desdobramento se dá por repetição até a inércia. A matéria é um obstáculo constante para o esforço finito da vida, e, portanto, foi mirando a ela que a evolução das espécies e a evolução da inteligência se desenvolveram. A inteligência se constituiu para observar e vencer a materialidade, mas os fenômenos da vida ultrapassam as ferramentas de medição e manipulação dos corpos construídas pela inteligência. A manipulação do intelecto ocorre apenas depois que a inteligência reconhece o corpo como distinto e determinado, mas dentre os corpos, alguns se constituem como verdadeiros centros de indeterminação, e podemos lhes imputar o estatuto de um grupo privilegiado de análise. Esses grupos são os corpos orgânicos, que lançam indeterminação na matéria inerte e criam imprevisibilidade, contingência e liberdade nos fenômenos.

[...] ao passo que a subdivisão da matéria em corpos isolados é relativa à nossa percepção, ao passo que a constituição de sistemas fechados de pontos materiais é relativa à nossa ciência, o corpo vivo foi isolado e fechado pela própria natureza. Ele compõe-se de partes heterogêneas que completam umas às outras. (BERGSON, 2010, p. 27)

No inorganizado temos a necessidade de agir; é no mundo material que precisamos nos alimentar, nos proteger do frio e construir abrigo. Como nos alerta Bergson: a faculdade de julgar é um anexo da faculdade de agir. Isto quer dizer que antes havia a necessidade da ação, e o ser humano, desprovido de vantagens ofensivas para caça e defensivas contra predadores, adaptou-se como artífice, 
criando instrumentos inorganizados para dar a ele o que a natureza o privou, e a partir daí desenvolveu novos usos para antigas ferramentas para auxiliá-lo em outras atividades, e assim aperfeiçoou indefinidamente seus instrumentos; ferramentas como um machado, a lógica e a linguagem. O mais importante é que a materialidade se adapta às exigências de nossa percepção, isto é, sua homogeneidade descontínua aceita nossa divisão em objetos que por sua vez podem ser fechados em sistemas isolados, como procede a ciência. Porém a divisão da matéria em conjuntos é relativa à nossa inteligência porque (como nos confirma a ciência contemporânea das partículas subatômicas de nível quântico) nos pormenores da matéria encontramos a volatilidade e instabilidade que caracteriza a consciência nos seres vivos. O inorganizado (o âmbito da matéria inerte) é regido por uma lei simples onde "o presente não contém nada mais que o passado, e aquilo que se encontra no efeito já estava na sua causa" (BERGSON, 2010, p. 29). Porém essa lei não pode ser aplicada indiscriminadamente a evolução da vida e da consciência, onde o presente transborda o passado, e cria o porvir enquanto avança.

Quando fragmentamos os corpos organizados, vemos os membros guardando os órgãos, os órgãos constituídos por tecidos, e os tecidos formados por células, que constituem o núcleo dos corpos orgânicos com funções próprias, como alimentação, digestão e reprodução. "Quem dirá onde começa e onde termina a individualidade, se o ser vivo é uno ou múltiplo, se são as células que se organizam no organismo ou se é o indivíduo que se dissocia em células?" (BERGSON, 2010, p. 8). O que é a individualidade e onde ela se encontra? Se um indivíduo é um centro de indeterminação onde suas propriedades vitais nunca estão plenamente realizadas (estando sempre em vias de realização pelo processo denominado ontogênese) e onde, se efetuarmos uma divisão, encontramos uma diversidade grande de órgãos integrados ao simples funcionamento do conjunto, concluímos então que a individualidade que o organismo parece possuir nunca se realiza, e é apenas uma tendência. Porque ao mesmo tempo em que o indivíduo é compelido à agir segundo suas necessidades individuais, ele também é atraído ao outro para a vida social ou o acasalamento; isto é, a própria necessidade da reprodução coloca o indivíduo de novo em interação, e por isso "a individualidade instala o inimigo em sua própria casa".

A vida, em seu esforço ascendente e finito através da materialidade, progride como um feixe, e essa tendência manifesta-se através da variabilidade dos seres vivos resultante da união sexuada e da mutação, que deste modo consegue alcançar, em alguma forma adotada no tempo, a adaptação necessária ao meio. A filosofia 
bergsoniana procura estabelecer e duração e a criação imprevisível de formas no âmago de uma filosofia da vida, isto é, onde mudança é constante e o próprio estado em que nos encontramos é em si mesmo mudança. Por isso de cima a baixo na escala dos seres vivos, em organismos unicelulares como na ameba e em organismos pluricelulares como no homem, vemos o mesmo processo de envelhecimento. "Em todo lugar onde alguma coisa vive, existe, aberto em alguma parte, um registro onde o tempo se insere" (BERGSON, 2010, p. 31). Por consequência dizemos que o ímpeto vital é finito e que o ser vivo está sempre em vias de realização, porque é o processo de morte ou a aquisição progressiva de certos elementos tóxicos, ou a perda gradual de elementos vitais, impedindo que o organismo seja o mesmo em dois instantes consecutivos. Mas de germe a germe a vida se atualiza e se cria novamente e indefinidamente.

Os estágios da vida embrionária nos oferecem um magnífico exemplo para pensar o envelhecimento. Segundo tese bastante difundida pelo pesquisador darwinista Haeckel na Alemanha da virada do século $X X$, os estágios do embrião percorrem o passado evolutivo de sua história, isto é (partindo do exemplo de um embrião humano): surgimos a partir da união do óvulo com o espermatozoide em uma célula, essa célula então se auto replica (onde o simples se desenvolveu em complexo a partir dos organismos unicelulares), desenvolvemos então uma cauda que se parece com a de um girino (os primeiros seres vivos eram aquáticos), depois membros aparecem e a cauda se parece mais com um rabo; esse rabo se transforma em nossa coluna, e em certos estágios desse desenvolvimento, o embrião humano é bastante parecido com o embrião de um elefante ou de um cachorro ou de qualquer outro animal vertebrado. Segundo essa tese, portanto, a ontogênese recapitula a filogênese. Hoje se refutou essa ideia de que um organismo atravessaria os estágios evolutivos anteriores à sua complexidade. Se levarmos ao pé da letra esta teoria, nós humanos, em nosso processo embrionário, passaríamos pela forma de um peixe adulto e de um macaco desenvolvido. O estudo da embriologia comparada atual nos mostra que todos os seres do reino animal possuem a mesma estrutura de desenvolvimento no início do processo embrionário: todos nós partimos para a jornada da vida a partir da forma de zigotos, onde a multiplicação celular começa a realizar seu trabalho, chegando ao fim e ao cabo apenas com a morte. Além disso, de uma maneira mais ampla, todas as células que constituem tanto os vegetais quanto os animais são células eucariontes, que são os verdadeiros tijolos com que a vida criou seus edifícios. 
Quando falamos de juventude, idade adulta e velhice (a ontogênese do organismo), apenas rotulamos com palavras momentos distintos de um mesmo movimento, sendo o processo de destruição orgânica o que de mais certo temos na vida, e, segundo Bergson, o único dado passível de ser usado nos cálculos da ciência. Por outro lado, nos fenômenos evolutivos de criação orgânica, nada temos que poderia ser reduzido ao dado. O momento atual de um ser vivo não pode ser reduzido ao momento imediatamente anterior, mas é o resultado de um passado muito antigo, que se manifesta na hereditariedade e na memória orgânica junto com as pressões externas do ambiente. Nesse passado que associa em parentesco as espécies, vemos a ação realizar-se antes em ideia que em ato, e onde o ser vivo projeta antecipadamente uma representação virtual daquilo que necessita materialmente. Por isso Bergson afirma que a consciência é coextensiva à vida, sendo o exemplo da ameba de extrema valia. Esse pequeno ser unicelular projeta para o ambiente pseudópodes (pequenos tentáculos ou filamentos) que utiliza para agarrar alimento. Esse organismo não possui visão ou tato, pois é composto de uma única célula, mas possui já uma vontade que se manifesta na sua procura e em seu esforço para encontrar alimento.

Para Darwin a natureza é uma batalha de uma espécie contra outra e de um indivíduo contra outro, em um processo que a competição determina o progresso da evolução. Mas no todo vemos a presença de uma equilibrada harmonia. Os grupos são complementares uns aos outros e se equilibram em um sistema regulado de alimentação e nascimento, fertilização e morte. Bergson defende a harmonia, mas admite numerosas discordâncias, "por que cada espécie, e até cada indivíduo, não retém do impulso global da vida senão um certo ímpeto, e tende a utilizar essa energia no seu próprio interesse; nisso consiste a adaptação." (BERGSON, 2010, p. 66). A complementaridade (termo que Bergson prefere ao de harmonia), apenas se manifesta em bloco e "mais nas tendências que nos estados". Cada organismo vivo busca sobreviver e se alimentar e então reproduzir; um processo preponderantemente egoísta até alcançar o nível da inteligência humana quando desenvolvemos a ética, a moral e a religião.

Assim, esboçando um rápido quadro da vida, os vegetais e os animais por um lado, e os insetos e os vertebrados separados na linha dos animais, representam as grandes cisões que se propagaram na terra. Os vegetais retiram seus nutrientes do solo e com a função clorofílica absorvem a energia do sol. Aí reside a base da cadeia alimentícia do reino animal. Os animais ou são vegetarianos, ou se alimentam de 
carne de animais vegetarianos. Portanto, toda a energia que utilizamos provém da fonte solar. Por isso a vida se caracteriza por dois atributos, (1) a propriedade de armazenar energia e, (2) na capacidade de liberar essa energia acumulada em movimentos indeterminados.

Por estarem presos ao solo, os vegetais estão imersos em torpor, mas seu crescimento guarda em si a indeterminação da queima da energia acumulada. Já os animais, pela necessidade do movimento para se alimentar, desenvolveram sistemas locomotores e concomitantemente um sistema nervoso para controle e processamento dos dados dos sentidos e do sistema motor. Assim, o desenvolvimento da consciência rumo à inteligência acompanha uma crescente complexidade do sistema nervoso até o cérebro dos vertebrados. Enquanto os elementos nervosos estão dispersos, a consciência se restringe a resposta mecânica de estímulos, mas quando os nervos vão se organizando rumo a centralização em um órgão como o cérebro, com funções de gerenciamento e comando, vemos a cognição se aprimorar e a inteligência emergir. Bergson então parece aderir à correspondência entre os estados físico-químicos do cérebro e seus conteúdos representacionais. Porém, como veremos mais adiante, com a inteligência o ser humano exteriorizou-se de si mesmo para a matéria, e podendo distender-se mais que a própria matéria. A sua representação, portanto, ultrapassa o cintilar das fosforescências do cérebro.

O movimento não se adapta ao torpor, e acompanhando a locomoção do animal desenvolveu-se instinto e inteligência para vencer a materialidade. Para Bergson aqui se comprova mais uma vez o elã comum a todas as espécies biológicas, porque esses quadros de torpor, inteligência e instinto não são fixos: o animal pode cair em torpor vegetativo (como no caso dos parasitas, e como questiona Bergson, não seriam também as plantas parasitas da terra?), e a planta pode acordar para certa animalidade (como no caso da planta insetívora, que desenvolveu estratégias para buscar nutrientes fora de um solo pobre de minerais e nutrientes). Essas estratégias que equiparam o ser vivo com primorosas habilidades não passam de tendências que podem ser desenvolvidas ou atrofiadas devido a seu uso ou desuso. Neste sentido Bergson está mais próximo dos transformistas que dos darwinistas e neo-darwinistas, onde o esforço do indivíduo é o fator essencial para despertar novas formas desejadas. Essa ideia, desenvolvida na França por Lamark, se adéqua muito bem à evolução bergsoniana por suportar a criação e a novidade no tempo (como veremos mais adiante, Bergson não se deixa levar pela passiva ideia darwinista de adaptação, e propõe uma nova concepção positiva ao termo). O que falta ao lamarkismo segundo Bergson, é a concepção do elã, pois para Lamark as transformações decorrem do 
esforço do indivíduo, e para Bergson, além do esforço existe uma tendência à mudança, e a determinados caminhos a serem traçados, como por exemplo o caminho que conduziu à mobilidade dos animais e ao cérebro dos vertebrados.

Para assegurar a compreensão da origem comum das espécies, precisamos notar que na evolução obtêm-se resultados idênticos em linhas de evolução divergentes, isto é, um órgão como o olho é encontrado no pente, um molusco marinho, e nos mamíferos terrestres. Além disso, como não se espantar com os progressos paralelos que plantas e animais realizaram rumo à sexualidade? Como explicar esses desenvolvimentos de propriedades idênticas em linhas de evolução divergentes senão por uma tendência comum, onde dadas as mesmas condições a organismo de meios diferentes, a mesma solução é atualizada? Segundo Bergson, as teorias evolutivas hegemônicas de sua época não conseguiram explicar esses fenômenos.

Os dois atributos essenciais da vida junto a origem comum das diferentes estratégias adotadas no percurso evolutivo é o que Bergson denomina elã vital. É por ser uma tendência que se atualiza na forma de um feixe que esse elã é por essência duração, contrário à materialidade. Para Bergson, a inteligência é incapaz de apreender esse elã, pois formou-se pela e para a matéria, e no material a inteligência só percebe estados distintos e formas fixas, mas que são em essência mistos de duração e espaço, e elementarmente vibração. A inteligência ignora o devir em favor da espacialidade para poder representar a repetição a partir da estabilidade e dessa forma agir no mundo. Favorecer a espacialidade em detrimento da duração é o que constitui propriamente a inteligência. Os dados provenientes dessa forma de recortar a realidade são polidos para acomodarem-se às necessidades da práxis. É impossível para a inteligência apreender o elã vital, pois este extrapola os conceitos de uno e múltiplo. Por isso Bergson irá caracterizar esse impulso como unidade múltipla ou multiplicidade una. Isto porque a atualização da vida, isto é, os seres viventes, carregam de maneira virtual todo o passado evolutivo que conduziu até sua presença atual. O virtual da vida é justamente esta memória que permanece junto à atualidade vivida. Em oposição a essa multiplicidade de interpenetração recíproca da duração temos a multiplicidade distinta do número. Nesta os pontos são estados, paradas, repetições da unidade básica. O número, portanto, faz parte da inteligência na sua disposição de recortar o real e construir o devir a partir de imobilidades.

O pensamento geométrico é natural ao espírito humano e podemos dizer que inteligência e geometria são uma e mesma coisa, pois ambas nascem das 
necessidades da vida prática. O número, base das manipulações geométricas, é essencialmente homogêneo, pois das mais simples as mais complexas operações matemáticas a unidade é sempre a mesma, e um número grande é a reunião de várias unidades idênticas. A partir do número os princípios racionais se desenvolveram; princípios como de identidade e o de não contradição, e a normatização da causalidade como o princípio da razão suficiente. Número e princípios racionais advém da ideia da impenetrabilidade dos corpos sólidos, onde um só corpo pode ocupar um determinado espaço, da mesma maneira que uma unidade é sempre idêntica à outra, e o processo de adição a justaposição desses elementos idênticos. Daí, consequentemente, desenvolve-se toda a nossa lógica. A inteligência é, segundo Bergson, a lógica aos sólidos, isto é, a faculdade que assenta no material e nos projeta para o futuro de maneira utilitarista. A nossa inteligência trabalha da mesma maneira quando pensa o espaço e a duração, e nesse sentido acaba por espacializar o tempo, cobrindo a duração com as mesmas vestimentas que se ajustam à repetição da matéria inerte.

[...] a inteligência humana, nas medidas que se amolda às exigências da ação humana, é uma inteligência que procede ao mesmo tempo por intenção e por cálculo, pela coordenação de meios para um fim e pela representação de mecanismos de formas cada vez mais geométricas. (BERGSON, 2010, p. 60)

Porém os fenômenos evolutivos e psicológicos nos apresentam heterogeneidade contínua, onde cada estado é diferente do anterior (embora o contenha como lembrança). Portanto nem a mecânica e nem o cálculo podem nesses âmbitos aplicar suas funções com segurança, e por isso a vida não é da alçada do número. Um número em uma variável aplicada a uma função ocupa um lugar de relação estrita com os termos que faz vizinhança. O conhecimento de um sistema artificial ou matemático incide apenas sobre as extremidades, enquanto 0 conhecimento dos fenômenos psicológicos e da vida incidem sobre a duração, sobre o intervalo; lugar precisamente negligenciado na matemática, que se baseia na ideia que tudo é dado e que podemos reconstituir presente, passado e futuro a partir da reunião dos fragmentos manipulados pela inteligência. Na trajetória de t1 para t3 temos $\mathrm{t} 2$ ocupando uma posição intermediária entre a posição inicial e a final. Porém essa forma de significar a realidade e representá-la é retroativa. Assim, de t1 para t2 poderíamos ainda repartir o intervalo em mais estados, criando quantas paradas se quiser, mas deixando sempre escapar a duração, como fumaça entre os dedos.

Para compreendermos o que Bergson pretende quando imputa à intuição a tarefa de superar a inteligência, precisamos saber quais são as vestimentas prontas 
que a inteligência dispõe para pensar a matéria, e consequentemente a vida e a consciência. Essas vestimentas são mecanismo e finalidade, e quando saltam do inerte para o vivo, cometem erros intransponíveis.

O mecanicismo data desde Demócrito, quando declara que o que há de real no corpo é o átomo, um elemento indivisível sem propriedades físicas apenas com atributos matemáticos ou geométricos. Nesse universo de Demócrito encontramos um vasto mecanismo onde os átomos, unidades homogêneas imperecíveis, movem-se através de leis definidas em uma eterna atualização do dado. Descartes ignora a presença dos átomos, e constitui a matéria pela extensão e pelo movimento. $\mathrm{O}$ ideal cartesiano é de que a única coisa real nos corpos é aquilo que serve para o cálculo, porém como calcular as sensações? A matemática chega apenas à extensão pela geometria, e ao movimento pela mecânica, e o movimento de que se trata aqui não é o movimento evolutivo ou dos fluxos de consciência, mas movimentos quantificáveis. O ponto em comum entre Demócrito e Descartes é que um e o outro concebem a matéria como desprovida de iniciativa, como uma coisa estéril e passiva às leis da matemática. Nessas teorias, quem conhecesse exatamente a posição dos corpos poderia reconstituir o futuro e o passado. Portanto o mecanicismo procura governar todas as transformações (inclusive as evolutivas) e prever os movimentos dos objetos através de funções matemáticas. Nessa linha poderíamos dizer que o mecanicismo chegaria à explicação definitiva do universo quando sintetizasse uma formula algébrica única (unindo geometria e mecânica), que permitiria não só prever o futuro, mas reconstituir todo o passado em qualquer momento do tempo.

Por outro lado, o finalismo, que é até mesmo anterior ao mecanicismo por ser mais natural ao espírito humano, também busca neutralizar a novidade para sustentar o conhecimento em gêneros e leis. Aonde tudo muda e nada permanece idêntico, reina o caos e a desordem, e por isso tanto mecanicismo quanto finalismo neutralizam e esterilizam o potencial criador imanente a todo ser vivo para assentar-lhes no eterno e na previsibilidade mecânica. Para Leibniz, por exemplo, o mecanicismo é suficiente quando empregado para explicar as camadas superficiais da realidade, mas não vai suficientemente longe para descrever as propriedades fundamentais da matéria. Dizemos que o finalismo é mais natural a nossa inteligência porque nele exteriorizamos para o mundo a representação que fazemos de nós mesmos. Assim, como somos forças e nos sentimos dotados de uma força (a res cogitans cartesiana), exteriorizamos nossa força para todas as partes da matéria, isto é, no monadismo de Leibniz, por exemplo, temos o corpo como um composto de mônadas, forças 
imateriais, verdadeiras almas análogas a nossa, embora mais simples. Mesmo as mônadas de uma pedra possuem vontade, mas sua vontade se resume a uma única representação, no caso, sua relação necessária com a gravidade. Quando essas mônadas se agregam apresentam a aparência da extensão, mas são, na verdade, forças imateriais. Se a extensão e a materialidade são aparências suscitadas pelo agregado de mônadas, onde cada uma é uma existência espiritual autônoma, seguese que existe uma hierarquia dos seres para garantir a unidade da função apesar da complicação da estrutura, e neste ponto estamos muito próximos de Aristóteles e sua classificação biológica. O finalismo antigo concebe uma atração proveniente da ideia de bem, como em Platão. E Aristóteles leva ainda mais longe a teleologia na natureza quando imputa toda a variedade natural à criação divina de um primeiro motor, que dividiu os seres através de uma única tendência que se dirige rumo à razão. Leibniz irá classificar essa hierarquia através dos conceitos de alma e espírito, sendo as almas a matéria viva, capaz de sentimento e memória, e os espíritos as almas dotadas de racionalidade. Assim um corpo humano seria formado por mônadas que se sujeitariam ao comando espiritual, racional, para organizar então todas as funções do organismo.

\begin{abstract}
Um plano é o termo que se estabelece para um trabalho, que fecha o futuro cuja forma desenha. Perante a evolução da vida, pelo contrário, as portas do futuro permanecem escancaradas. É uma criação que prossegue infindavelmente graças a um movimento inicial. Esse movimento constitui a unidade do mundo organizado, unidade fecunda, de infinita riqueza, superior ao que nenhuma inteligência poderia sonhar, visto que a inteligência é apenas um dos seus aspectos, um de seus produtos. (BERGSON, 2010, p. 122)
\end{abstract}

Para Bergson, tanto finalismo quanto mecanicismo não abordam de maneira correta os domínios da vida. O mecanicismo vai longe demais em seu ideal de matematização quando pretende que todos os objetos materiais possam ser representados por um número e que todo movimento possa ser descrito por uma função no plano cartesiano. Como nos mostrou Bergson, a evolução da vida e dos estados de consciência não estão na mesma dimensão que as abstrações matemáticas. Por outro lado, o finalismo, quando atribui existência imaterial a todos os átomos ou mônadas e concebe um plano que dirige todo o movimento do real, não leva suficientemente longe seu princípio dinamista ao relacionar todos os seres a uma atração exercida pelo ideal de bem aristotélico. Sendo assim, as ciências biológicas devem realizar um esforço para se desvencilhar da inteligência e de suas vestimentas para só então empreender o escrutínio da ideia de duração - que é a matriz da evolução da vida e de toda ciência que se quer verdadeiramente psicológica. Apenas através de uma análise da genealogia crítica da inteligência se poderá erigir uma 
ciência psicológica e verdadeiramente biológica, e o princípio do movimento evolutivo será o elã vital, o portador da tendência psicológica da duração.

\begin{abstract}
Não contestamos de forma nenhuma que a adaptação ao meio seja a condição necessária da evolução. É por demais evidente que uma espécie desaparece quando não se amolda às condições de existência que se lhe ofereceram. Mas uma coisa é reconhecer que as circunstâncias exteriores são forças com as quais a evolução não pode deixar de contar, e outra coisa é afirmar que sejam elas as causas determinantes da evolução. Esta última tese é a do mecanicismo, e exclui totalmente a hipótese de um impulso originário, quero dizer, de um ímpeto interior que impulsionaria a vida, por meio de formas cada vez mais complexas, para destinos cada vez mais elevados. (BERGSON, 2010, p. 119)
\end{abstract}

Precisamos agora adentrar mais a fundo nas teorias científicas da evolução para compreendermos a crítica bergsoniana endereçada a elas. É fundamental para isso analisarmos o conceito de adaptação, conceito este que nos permite perceber como mecanicismo e finalismo são utilizados de forma indiscriminada nas ciências biológicas. Por um lado, afirma-se que esse conceito é o acumular de pequenas variações, e que a partir do acaso efetua-se melhoramentos nos indivíduos de uma espécie, melhoramentos que garantiriam a esse indivíduo vantagens que se refletiriam em sua aptidão ao meio e que, consequentemente, ele disseminaria através da procriação às gerações futuras. Porém, Bergson logo declara um problema que essa tese não pode resolver: o acaso operar esse lento processo de acumulação de pequenos avanços não pode explicar o aparecimento de órgãos com semelhanças fisiológicas idênticas em linhas evolutivas divergentes. Exemplos de casos assim são numerosos, como a sexualidade nos vegetais e animais, e um órgão como o olho, presente em linhas evolutivas a muito tempo separadas no tempo.

[...] o neolamarkismo é a única das formas atuais do evolucionismo capaz de admitir um princípio interno e psicológico de desenvolvimento, embora a ele não recorra necessariamente. E é também o único evolucionismo que nos parece ter uma explicação válida para a formação de órgãos complexos idênticos em linhas independentes de desenvolvimento. (BERGSON, 2010, p 94)

Bergson refutou e rejeitou qualquer traço de mecanicismo em seu evolucionismo filosófico, e rejeitou também o finalismo embora tenha aproveitado retalhos dessa filosofia, invertendo a atração que a filosofia aponta para um fim, para um impulso inicial que a vida leva adiante de maneira indeterminada. O darwinismo é rejeitado no bergsonismo por empregar ao acaso a função de adaptar os organismos nas populações e ao meio ambiente. Essa forma de empregar o termo é passiva, e 
Bergson defende uma abordagem ativa do mesmo. Isto é, a adaptação passiva é aquela em que o organismo sobre a influência do meio e não transforma ou canaliza essa pressão para certo resultado: caso esteja adaptado sobreviverá, caso contrário sua morte é certa. Em uma abordagem ativa da adaptação, o organismo tira dessa influência ou pressão do meio um proveito apropriado, de uma forma propriamente criadora.

Se a evolução é uma criação que se renova incessantemente, vai criando pari
passu, não só as formas da vida, mas as ideias que permitiriam a uma
inteligência compreendê-la, os termos que serviriam para a exprimir. Quer
dizer que o seu futuro transborda do seu presente, e não poderia delinear-se
nele como ideia. (BERGSON, 2010, p. 120)

A inteligência é a estratégia adotada pelo ímpeto vital que mais longe levou esse elã em sua superação dos obstáculos materiais. Porém a filosofia por comodidade ocultou qualquer traço de criação e novidade na esfera biológica e psicológica. O objetivo de Bergson é então erigir uma metafísica positiva a partir de um empirismo rigoroso, e para isso é necessário conhecer o objeto de seu empreendimento: a evolução da vida e da matéria, o organizado e o inorganizado, instinto e inteligência. Os corpos inorganizados são decomponíveis por nós em fragmentos, e caso mudem, mudam sob a influência de uma força exterior, mas permanecem aquilo que eram antes do movimento. Assim, representamos a mudança como o deslocamento de partes que não mudam. Mas o movimento evolutivo é coisa muito diferente, onde o presente da forma não pode ser explicado pelo passado que a antecedeu, e seu futuro não pode ser previsto.

A representação do conjunto da vida não pode consistir na combinação entre si das ideias simples em nós depositadas pela própria vida no decurso da sua evolução: como poderia a parte equivaler ao todo, o conteúdo ao continente, um resíduo da operação vital à própria operação? (BERGSON, 2010, p. 65)

Para Bergson a inteligência é incapaz de compreender o amálgama de espaço e tempo, e essencialmente incapaz de analisar a verdadeira duração das coisas. E por isso, segundo Worms em seu livro Bergson, ou os dois sentidos da vida, "a vida fornece um exemplo privilegiado de uma realidade que só se pode compreender por um esforço crítico de nosso conhecimento sobre si mesmo." (WORMS, 2011, p. 189). Esse esforço crítico é resultado da reflexão sobre o significado da vida enquanto evolução, reflexão esta que já é uma superação da inteligência sobre si mesma, pois é no estável - que preside o número, a matemática e a linguagem - a dimensão onde as ferramentas são talhadas pela inteligência, mas, no entanto, todas essas 
ferramentas são inúteis para abordar a real sucessão da vida que passa como o desdobrar dos estados de consciência. Como nos lembra Bergson, estamos mudando sem cessar, e o próprio estado em que nos encontramos é em si mesmo mudança, isto é, somos uma duração que se acumula e que faz uma bola de neve consigo mesma. A mudança aqui possui existência real, é a substância da realidade, e seu conceito é a pura diferença, que nunca se deixa apreender.

[...] não há diferença essencial entre passar de um estado a outro e persistir no mesmo. Se o estado que "permanece o mesmo" é mais variado do que supomos, inversamente a passagem de um estado para outro é mais semelhante do que se imagina ao prolongamento de um único estado; a transição é contínua. (BERGSON, 2010, p. 16)

Porém o fluxo de consciência não é aleatório e está enraizado na situação presente para ajudar na situação futura e realizar um trabalho útil. Neste processo o mecanismo cerebral trabalha recalcando o inconsciente, a filtrar aquilo que atrapalharia a ação e que desviaria a atenção do indivíduo de obter o que se necessita. Temos ao nosso dispor todo nosso passado como memória, isto é, a memória nunca se perde e permanece virtualmente presente, e dado um estímulo externo, a memória apropriada é escolhida dentre outras por um movimento de contração e tensão. Essa virtualidade é o que constitui o nosso caráter, isto é, o acúmulo de todas as nossas experiências como lembranças, e quando atualizadas se transformam em imagens, fundidas com a percepção, e que determinam nossas ações. Nesse processo de fundição da memória com a percepção presente algo novo é criado. Bergson em um estudo anterior, demonstra que memória não está circunscrita em nenhuma região determinada do cérebro, e que as doenças da memória afetam mais os mecanismos de resgate da lembrança que a lembrança em si. O cérebro é aqui entendido como um órgão mediador entre os nervos dos sentidos e os nervos motores, e a consciência transborda de seu concomitante físico. A percepção presente é memória no sentido que perceber é desenhar nossa ação possível no mundo. A passagem da percepção à realidade é uma diferença de grau, sendo a passagem da memória para o real uma diferença de natureza. Isto porque o que percebemos é um recorte do real, um recorte que privilegia certos aspectos do objeto que nos interessa, e negligencia aspectos inúteis, neste sentido a passagem da percepção ao objeto é uma diminuição ou empobrecimento, a percepção é pois menos que a realidade. Porém a memória acrescenta à essa percepção associações por contiguidade e semelhança, dotando a percepção com uma tonalidade nova, carregada com juízos e idiossincrasias próprias 
do organismo que percebe. Bergson se coloca nessa questão entre o idealismo e o realismo científico. Segundo Bergson ambos estão errados, o idealismo quando dota as ideias com uma existência independente do real, alimentando um dualismo cartesiano ou um eterno de essência platônica. O realismo, quando pretende que os estados cerebrais são equivalentes a fenômenos psíquicos. Para Bergson o máximo que se pode afirmar é que estão associados, e isto não se pode negar, mas da associação para a equivalência é um salto que não corresponde às observações empíricas.

Todas as teorias até aqui levantadas ou são inúteis para a abordar o vivo (como o caso do mecanicismo e do realismo científico), ou devem ser transformadas (como no caso do finalismo e do neolamarkismo) para abordar o fenômeno vital. A própria inteligência evita descrever a criação do novo para aplacar a imprevisibilidade presente nos fenômenos evolutivos e psicológicos. A ciência não poderia se estabelecer sem erigir para si mesma fundamentos sólidos. Ao realizar esse trabalho de síntese do primeiro capítulo, visa-se obter claramente a distinção entre o sentido da matéria e o sentido da vida no bergsonismo, e como finalismo e mecanismo são insuficientes para apreender o elã vital. Como nos aponta Bergson ainda na introdução do livro:

"[...] em um primeiro capítulo, provamos, no progresso evolutivo, as duas vestimentas de confecção, de que nosso entendimento dispõe, mecanismo e finalidade; mostramos que nem uma, nem outra servem, mas que uma das duas poderia ser novamente cortada e recosida, e, sob essa nova forma, cair menos mal que a outra" (BERGSON, 2010, introdução)

Portanto foi necessário perpassar criticamente as formas que a inteligência criou para agir no mundo e representar o devir, formas estas que determinaram o crescimento do conhecimento até a ciência moderna onde uma revolução conduzida pela astronomia transformou a forma de conceber o tempo, mas que, no entanto, manteve os postulados da ciência dos antigos de que o móvel é composto de imobilidades. Mecanicismo e finalidade representam o fundamento das teorias cosmológicas e tratados dos filósofos, e em um sistema fechado, muitas vezes se passa de uma a outra vestimenta de forma indiscriminada para responder a diferentes problemas. Ao demonstrar as insuficiências dessas teorias para conceber o fenômeno da vida, erigimos o conceito de elã vital, que é incompreensível tanto para uma quanto para outra forma do entendimento. Agora realizaremos o escrutínio das diversas tendências tomadas por esse elã com o intuito de vislumbrarmos a real função da inteligência humana no intrincado jogo de forças divergentes em que foi concebida. 


\section{2 instinto e inteligência}

"Instinto e inteligência representam, pois, duas soluções divergentes, igualmente elegantes, de um único problema." (BERGSON, 2010, p. 161)

No segundo capítulo do livro, Bergson visa aproximar as principais linhas de evolução da vida para evidenciar as características próprias de cada tendência, e então, nos capítulos 3 e 4 do livro A Evolução Criadora, delinear o conceito e a crítica da inteligência. Como já assinalamos por antecipação neste estudo, essas tendências divergentes são: torpor, instinto e inteligência. É importante termos como claro o que é o instinto porque parte dele a noção de intuição bergsoniana, que será a chave para superar as limitações da inteligência, e superar a condição humana. Precisamos levar em conta que a evolução bergsoniana não se efetua através de associação, mas de dissociação, isto é, sempre por divergência de esforços, onde a partir de uma identidade originária o processo evolutivo se propaga em feixe, afastando uma tendência complementar de outra.

Os elementos de uma tendência não são comparáveis, com efeito, a elementos justapostos no espaço e exclusivos, mas antes a estados psicológicos; cada um dos quais, tenha ele sido o que for, participa todavia dos outros e contêm assim virtualmente toda a personalidade a qual pertence. (BERGSON, 2010, p. 136)

Assim, cada manifestação da vida apresenta os caracteres das outras manifestações, e consequentemente as tendências opostas subjazem umas nas outras como recordações que podem vir a despertar. Porém, quando uma tendência se desenvolve, ela especializa-se, e nessa especialização algumas características das tendências complementares são incompatíveis com a especialização adquirida. Por isso uma tendência solapa a outra, como no nosso caso, em que a inteligência dominou nossa perspectiva em relação tanto a matéria quanto a vida, solapando o instinto, mas onde a intuição e o instinto despertam em raros casos quando o perigo nos espreita. Para compreendermos como uma tendência está implícita na outra será necessário demonstrar a estrita relação que a consciência mantém com o movimento dos animais e como a fixidez da planta é o fator de seu torpor e inconsciência.

Tanto os animais como as plantas possuem a tendência para uma crescente complexidade, mas nas plantas essa complexidade está condenada a insensibilidade e ao torpor, devido a sua imobilidade. Porém, nos animais, conforme se complexificam, vemos uma tendência para os nervos centralizarem sua operação e 
comunicação em um só órgão. Assim, foi devido a essa tendência de unificação dos elementos nervosos nos cérebros dos Vertebrados que os animais alcançaram a consciência e despertaram para o instinto e a inteligência. Na realidade a consciência já está presente a partir do momento que o organismo se move livremente, mas a inteligência e a consciência de si só se desenvolveram com a crescente complexidade do sistema nervoso. Bergson nos oferece uma metáfora para analisar o papel do cérebro em um organismo: ele funciona como uma central telefônica, fazendo a intermediação de comunicação entre dois extremos da linha. $E$ quais seriam esses dois extremos? De um lado estariam os nervos dos sentidos e os nervos musculares, e de outro as volições e desejos. Concluímos então que o cérebro nada mais realiza que conectar as volições às ações. Essa habilidade concedida pelo cérebro é fundamental para emergir a consciência de si através da inteligência. Mas encontramos inteligência em outros animais além do humano? Sim, pois há inteligência sempre que se manifesta inferência, isto é, na canalização de uma experiência passada visando uma experiência presente, e segundo Bergson, aí já se encontra vestígios de invenção. É o que vemos quando a raposa reconhece uma armadilha, ou quando certos mamíferos, como o elefante ou os primatas, fazem uso de ferramentas.

Como já dissemos no início deste estudo, para Henri Bergson a consciência é coextensiva à vida, e, portanto, "seria tão absurdo negar a consciência a um animal, por ele não ter cérebro, como declará-lo incapaz de se alimentar pelo fato de não ter estômago." (BERGSON, 2010, p. 128). Nos seres mais simples da escala animal os centros nervosos simplificam-se até o ponto de desaparecerem por completo em certos organismos (como já demonstrado no exemplo da ameba, como negar-lhe consciência e vontade, mesmo que rudimentares?). Porém as espécies, das mais indiferenciadas como a ameba as mais complexas como nós humanos, procuram sempre o mais cômodo para agir, isto é, procuram gastar o mínimo de energia possível para saciar suas necessidades. Essa tendência a se acomodar gera retrocessos e paradas evolutivas, e por isso a evolução da vida não pode ser concebida na forma de um progresso linear ou mesmo de forma hierarquizada, como entendia Aristóteles. $\mathrm{Na}$ vida, o perigo do torpor permanece à espreita, por assim dizer, e o movimento é essencial para levar a tocha da vida adiante para alcançar formas cada vez mais elevadas. Portanto, embora vegetais e animais tenham aberto as mais largas estradas por onde corre o elã vital, a tendência à mobilidade, e, portanto, a direção tomada pelos animais, representa verdadeiramente a direção fundamental da vida. 
Quando um animal móvel descobriu que poderia fazer de outros animais seu pasto, mais vorazes as espécies se tornaram umas para com as outras. Nesse ambiente hostil alguns animais procuram defender-se atrás de couraças, envolvendose em uma armadura que lhes dificultam os movimentos. Para Bergson esse ser está condenado a semi-dormência, porque sua estratégia de defesa diminui na proporção aritmética entre sua ação virtual e ação real, isto é, suas ações possíveis estão reduzidas pelo peso de sua armadura. Portanto Bergson nos alerta, na evolução da vida e nos destinos individuais, "os maiores sucessos foram obtidos pelos que aceitaram os maiores riscos". Por sucesso devemos compreender uma aptidão para se desenvolver nos mais variados meios de maneira a cobrir a maior extensão de terra possível, e nesse sentido a inteligência possibilitou ao ser humano um sucesso sem precedentes na evolução da vida, pois somos a única espécie que se lançou para fora da órbita terrestre, devido a nossa curiosidade ilimitada.

Ao longo do caminho seguido pela evolução do animal produziram-se desfalecimentos e decadências sem conta, ligados na sua maior parte a hábitos parasitários; são outros tantos desvios na direção da vida vegetativa. Assim, tudo nos leva a supor que o vegetal e o animal descendem de um antepassado comum, no qual estavam reunidas, em estado nascente, as tendências de um e de outro. (BERGSON, 2010, p. 131)

A inteligência que se desenvolveu ao longo da série dos Vertebrados e que culmina em sua apropriação de si mesma no ser humano, não é uma conquista fixa, e pode dar lugar ao instinto ou ao torpor caso as circunstâncias demandem. Da mesma maneira, as plantas possuem instintos, como podemos perceber ao observar o movimento realizado por certas plantas trepadeiras. Por isso, na inteligência sempre resta uma franja de instinto, e não há instinto que não seja acompanhado por vestígios de inteligência. Quando Bergson alega que uma característica geral da vida consiste em procurar o mais cômodo, ele nos alerta do perigo que nos espreita em relação ao torpor. Sem uma incansável curiosidade, própria de nossa inteligência, não teríamos alcançado as conquistas materiais e desenvolvimentos tecnológicos que obtivemos (sendo essas ferramentas e tecnologias como que extensões de nossos próprios órgãos).

Um fenômeno comum que perpassa as diferentes tendências criadas pela evolução é a consciência. Mas em que ela consiste? Segundo Bergson a consciência é a diferença entre a atividade virtual e a atividade real, isto é, ela mede a distância entre a representação e a ação do organismo (BERGSON, 2010, p. 163). Mesmo no organismo unicelular da ameba podemos ver como essa definição se aplica, levando 
em conta sua incessante e dispendiosa procura por alimento. Porém, enquanto nós seres humanos somos potencialmente conscientes de nós mesmos através de nossa inteligência, o instinto parece estar imerso na inconsciência, e neste ponto precisamos expor uma distinção entre duas formas de inconsciência. Uma é a consciência nula, e a outra a consciência anulada:

Consciência nula e consciência anulada são ambas iguais a zero; mas o
primeiro zero exprime que nada há, e o segundo que se trata de duas
quantidades iguais e de sentido contrário que se compensam e se
neutralizam. A inconsciência de uma pedra que cai é uma consciência nula:
a pedra não tem o menor sentimento de sua queda. Sucederá o mesmo com
a inconsciência do instinto, nos casos extremos em que o instinto é
inconsciente? (BERGSON, 2010, p. 162)

Para responder essa questão precisamos refletir sobre o fato, relatado por Bergson, de que a representação é arrolhada pela ação. Leibniz, em sua monadologia, já alertava que agimos como animais em $3 / 4$ de nossas ações. Isso quer dizer que na maioria de nossas ações cotidianas realizamos movimentos de maneira automática, como se estivéssemos imersos na inconsciência. O hábito enraíza-se profundamente em nosso espírito e desse modo quando realizamos a execução do movimento habitual, agimos de maneira inconsciente. A consciência anulada é própria do instinto, que guia o organismo de maneira inconsciente, mas precisa e plena. Mas não é o hábito que anula a consciência no caso do instinto, e sim uma simpatia entre o organismo e o objeto com que ele se relaciona. Precisamos diferenciar agora o que caracteriza o conhecimento no caso do instinto e o conhecimento no caso da inteligência, que constituem duas espécies diferentes de conhecer.

Para Bergson, tanto instinto quanto inteligência implicam conhecimento, mas no instinto esse conhecimento é inconsciente e representado, enquanto a inteligência obtém o conhecimento de maneira consciente e pensada. O ser humano tem a capacidade de evocar lembranças a sua vontade, sem que estas estejam determinando ou auxiliando a situação presente. Porém nos casos dos outros animais a recordação está cativa da percepção, manifestando-se pelo reconhecimento, e por isso Bergson afirma que este reconhecimento é antes interpretado do que pensado. Os insetos foram os que desenvolveram o instinto de maneira mais completa e perfeita: eles agem como se conhecessem seu objeto sem ter aprendido nada sobre ele. Assim procede a vespa que precisa depositar seus ovos no interior de uma lagarta, imobilizá-la com seu veneno para quando seus ovos eclodirem terem à disposição alimento para seu primeiro estágio de desenvolvimento fora do ovo. Essas vespas parecem saber onde devem picar a lagarta para a paralisar sem a matar, pois 
seus ovos, quando eclodirem, necessitam de alimento fresco para se alimentar, e não matéria orgânica já em decomposição. Poderíamos então dizer que se trata de um conhecimento inato? O que é inato nos organismos é a função do instinto e da inteligência, e esse conhecimento inato incide no primeiro caso sobre coisas e no segundo sobre relações. Assim, os insetos apresentam uma simpatia para com uma coisa, e conhecem o objeto com que se relacionam a partir de dentro, intimamente. Neste sentido existe uma simpatia entre a vespa e a lagarta, o que possibilita a precisão cirúrgica da ação da vespa para realizar com sucesso a sua necessidade reprodutiva. Já na inteligência, é a relação entre sujeito e atributo que é apreendida naturalmente. Por isso "a inteligência, naquilo que tem de inato, é o conhecimento de uma forma, o instinto implica a de uma matéria" (BERGSON, 2010, p. 167). O instinto, portanto, tem um conhecimento interno, implícito na ação. A inteligência possui um conhecimento externo, explícito na ação efetuada. Assim, a natureza do conhecimento instintivo incide sobre o que os filósofos classificam como proposições categóricas, enquanto a inteligência se exprime hipoteticamente.

Tudo se passa como se a força que evolui através das formas vivas, sendo
uma força limitada, pudesse escolher, no domínio do conhecimento natural
ou inato, entre duas espécies de limitação, uma incidindo sobre a extensão
do conhecimento, a outra sobre sua compreensão. No primeiro caso o
conhecimento poderá ser amplo e pleno, mas será restrito a um objeto
determinado. No segundo, o conhecimento não limita o seu objeto, mas é por
não conter mais nada, sendo apenas uma forma sem matéria. (BERGSON,
2010 , p. 169)

No caso do instinto seu conhecimento incidirá sobre um objeto determinado, sendo esse objeto a amplidão da vida em geral. Já no caso da inteligência seu conhecimento é uma forma sem matéria, isto é, a inteligência emprega uma mesma coisa para realizar funções diferentes. Bergson caracteriza o ser humano como Homo Faber devido a sua inteligência ser capaz de fabricar instrumentos não organizados. Podemos supor que a intuição do instinto seja superior a inteligência, mas na realidade essa intuição se reduz à porção de vida que interessa ao organismo. A inteligência por outro lado, por se adaptar exteriormente aos objetos, consegue vagar e divagar entre eles, e alargar seu domínio. Alargando indefinidamente seu domínio pôde então libertar-se, tornando possível novamente despertar as virtualidades da intuição.

O método cinematográfico do pensamento representa essa característica da inteligência condicionada pela situação presente e presa às justas vestes do finalismo e macanicismo. O passado moldando as ideias em representação e o futuro demandando planejamento e orientação da consciência do organismo. Assim, como 
em um rolo de película cinematográfica, a consciência se desenrola em um plano onde tudo é dado, e onde não resta espaço para a criação e a novidade do tempo. A inteligência, apoiada ao passado e debruçada sobre o futuro, perde o momento presente como o intervalo que separa os extremos em uma operação matemática, intervalo negligenciado na própria operação. A realidade, que é essencialmente duração e mudança, é recortada pela inteligência e transfigurada em uma associação de estados, de paradas e fragmentos desconexos.

O caráter essencialmente "cinematográfico" da inteligência consiste justamente em não seguir o movimento do objeto, em não obedecer ao "fio da experiência" e de reconstituí-lo no campo do descontínuo, introduzindo um intervalo entre as pulsações tornadas "fases". (PRADO JR, 1988, p. 62)

\section{Capítulo 2 - As duas ordens e a superação da inteligência}

Após traçarmos a perspectiva evolutiva bergsoniana nos dois primeiros capítulos do livro Evolução Criadora, faz-se necessário agora aprofundar a pesquisa nas ilusões da inteligência; ilusões provenientes de noções construídas para pensar o "devir em geral", mas fundadas sobre um plano prático de descontinuidades. Bento Prado Júnior interpreta a empresa bergsoniana como uma ontologia da duração, em detrimento à ontologia da repetição originada da práxis e fundada sobre uma miragem da Ausência pela tradição filosófica, que segue, ontologicamente, as disposições naturais do pensamento cinematográfico, isto é, dos processos mentais desenrolados através de um tempo espacializado, solapando a duração real como heterogeneidade de interpenetração. A inteligência como produto do impulso vital se desenvolveu a partir dos obstáculos da matéria visando adaptar-se a esses obstáculos, inserindo-se no mundo de maneira utilitarista para garantir a própria sobrevivência. A matéria é o perene obstáculo da vida pois entrava o livre fluir do impulso vital, mas, por um ângulo positivo, é ela que incita o impulso a novas formas, e demanda uma iniciativa criadora por parte do organismo, em um processo que conduziu a retrocessos evolutivos, paradas, e ao homem, onde o elã encontrou finalmente a consciência e a superação de si mesmo e por onde corre "por vias largas".

Em um sentido específico podemos dizer que o homem ocupa um lugar privilegiado no processo evolutivo, mas não podemos supor uma finalidade, onde a evolução se encaminhou para o ser humano, pois, como alerta Bergson, a própria estrutura adotada pela vida em nosso planeta sobre moléculas de carbono não é necessária, e em outras circunstâncias a vida poderia adotar formas inimagináveis e 
estruturas morais diferentes. Mas no humano a vida alcançou o auge de acumulação e da súbita liberação da energia acumulada. O sistema nervoso do homem possibilita um intervalo entre o estímulo recebido e a ação efetuada que abre margem para verdadeira e imprevisível criação. A ação é descontínua como o é toda a pulsação de vida, e no homem, consequentemente, o conhecimento será também descontínuo. $A$ faculdade de conhecer pela inteligência foi construída sobre esse plano de descontinuidade, e a questão que Bergson nos coloca a partir daí é: "sendo essencialmente prático, poderá ele [o intelecto] servir, sem ser modificado, para a especulação? " (BERGSON, 2010, p. 334). A natureza criou uma máquina (o cérebro humano) que ultrapassa o mero mecanismo e automatismo, constituindo aqui um paradoxo, pois o intelecto é o mais desenvolvido mecanismo da natureza.

A superação do intelecto ou o conhecimento propriamente especulativo aqui referido, deve ser compreendido de duas formas. Por um lado, a inteligência superou a matéria ao se colocar como Homo Faber, domesticando animais, cultivando sementes, criando ferramentas, em suma, desenvolveu cultura que prevê fenômenos naturais e provê uma conduta apropriada perante os fenômenos físicos. A superação neste sentido é do elã sobre a matéria. Porém o trabalho bergsoniano é em outro sentido, o de apontar para a superação da inteligência, que apesar de seus sucessos sobre a matéria é falha para abordar a esfera psicológica e compreender a vida e seu movimento próprio, e Bergson, junto com Nietzsche, aponta para um super-homem, pois é para além da mera sobrevivência e da inserção pragmática no real que subjaz a verdadeira felicidade. Superação deve ser entendida, fundamentalmente, como inversão da ordem natural do pensamento, para além do condicionamento de nosso mecanismo cinematográfico de pensar.

Mas se o sucesso da inteligência é óbvio, e o condicionamento que estamos sujeitos pelo mecanismo cinematográfico do pensamento em nossa vida prática e afetiva nos possibilitou obter o domínio da natureza e nos estabelecer como espécie dominante no planeta, porque então nos preocupar em ir além dessa nossa condição humana? A questão ao fundo parece ser a própria felicidade, ideal perseguido pelos filósofos para aplacar à angústia de nossa existência. A felicidade, segundo Bergson, seria possível numa absorção do indivíduo no todo, isto é, pela constatação antes sentida do que pensada de pertencimento da consciência individual com a natureza e com o cosmos, viragem qualitativa que só é acessível à consciência quando pela inteligência se realiza um esforço para retomar o instinto de forma desinteressada, e, estabelecendo-se na Presença da duração, coincidir com o objeto na imediaticidade 
de um tempo puro, sem memórias passadas nem projeções futuras, isto é, sem utilizar nesse trajeto as ferramentas conceituais da inteligência e sem utilizar a intencionalidade que visa a inserção prática do organismo no meio ambiente. A inteligência é uma ferramenta cunhada pela evolução da vida sobre o esforço de inumeráveis organismos, e usá-la requer atenção. O uso indiscriminado da inteligência em dimensões inacessíveis a ela é fruto de frustrações angustiantes e realce dos temores dos seres conscientes.

\footnotetext{
Uma humanidade completa e perfeita seria aquela em que essas duas formas de atividade consciente alcançassem o seu pleno desenvolvimento. Entre essa humanidade e a nossa é, aliás, fácil conceber muitos possíveis intermediários, correspondendo a todos os graus imagináveis da inteligência e da intuição. (BERGSON, 2010, p. 291)
}

A nossa humanidade é constituída preponderantemente sobre o comando da inteligência; à intuição ficou reservada a ação em lampejos descontínuos quando o organismo se encontra em perigo ou um interesse vital está em jogo. A sociedade se esforça em solapar por completo a intuição, através da educação e suas etiquetas, para que a inteligência seja a única humanidade possível. Porém o atual estado das coisas, e particularmente o comportamento do humano em frente as outras formas de vida evidencia ignorância, crueldade uma solidariedade restrita a poucos, longe de abarcar toda a humanidade. Por isso Bergson defende que a compreensão da vida, e a consequente construção de uma outra humanidade, só é acessível através de um salto qualitativo possibilitado pela intuição. A intuição compartilha com o instinto a simpatia com a vida, mas o ultrapassa na medida em que o instinto é um sinal aderente, isto é, é um conhecimento inato de uma coisa, ou uma forma específica do impulso vital. A intuição é o próprio espírito, e enquanto tal só pode ser vislumbrada pelo esforço inteligente do ser humano através da filosofia, por uma metafísica positiva. A intuição adere antes à própria mobilidade que a uma coisa determinada, como o faz o instinto. A inteligência por outro lado, adere à imobilidade, e dessa forma fragmenta o real, e o homem, conduzido pela inteligência está fragmentado do todo, e vive em angústia, atormentado pela solidão e apartado do absoluto. A filosofia nos insere na própria vida do espírito e a aproxima do corpo, cisão do corpo com o espírito efetuada pelo dualismo em filosofia, corte responsável pena inaptidão da consciência humana de pensar o movente e a vida. Bergson procura restaurar a unidade da vida mental, que é tanto instinto voltado à vida, quanto inteligência, voltada à matéria. Quando Bergson nos alerta que a vida é de essência psicológica ele já nos informa que para conhecer o sentido da vida é antes necessário conhecer e entender os 
mecanismos de nossa própria consciência. A inteligência ao adaptar-se para agir sobre a matéria só percebe o imóvel, a repetição, em suma, este universo morto e frio da matéria inerte. O salto qualitativo é possível primeiramente através de uma intuição sensível por um esforço da inteligência. Essa intuição prende-se à percepção pura, pré-linguística e imediata, buscando coincidir com os objetos a partir de dentro, sem conceitos e imagens.

A inteligência pode criar infindáveis ferramentas para manipular o inerte, mas é essencialmente incapaz de criação espiritual, tudo o que cria é material, melhorando a vida, facilitando a comunicação, porém a criação espiritual é de outra ordem. Segundo Bergson a alegria é o sentimento que se tem quando se percebe ter criado algo que subsistirá e enriquecerá toda a humanidade. Essa alegria pode ser experimentada, segundo Bergson, quando apreendermos a vida a partir de dentro, coincidindo com ela, e nesse movimento compreendemos o sentido da vida na atenção dada a nossa própria consciência, pois deste modo experimentamos a potência criativa imanente à vida que corre em nós, manifesta na duração e na multiplicidade contínua de nossa vida mental, e no funcionamento de conjunto ordenado e harmonioso de nosso próprio corpo, ambos manifestando a tendência criativa que corre por nós e nesse sentido somos nós propriamente criadores pois únicos, de corpo e mente, no movimento evolutivo. A inteligência é o ponto de partida em uma viragem onde a intuição toma as rédeas e a consciência instala-se no fluir da duração, imersa no presente, porém com acesso ao todo virtual do elã vital, expandindo assim toda a percepção pois se desliga do "fio da experiência", se afasta da tendência pragmática e empírica da atenção e se instala no eterno agora de infindáveis possibilidades e enriquecido com um virtual tão grande quanto de possíveis que se delineiam em sua atualização presente. A inteligência humana, enquanto intelecto pragmático e utilitarista, implica necessariamente angústia, pois visa sanar uma falta que se sente, e apenas a intuição poderia conduzir o homem a compreensão da vida e à felicidade, ao afastar a atenção das necessidades práticas e conduzir a consciência a profunda contemplação do movimento vital.

[...] a experiência da angústia aparece como uma regressão à pura subjetividade e como perda de contato com o real. É a alegria que, como aceitação do real e colaboração em seu engendramento, desempenha o papel de uma verdadeira transcendência, indicando para além de si mesma uma superação da subjetividade [...], poderíamos dizer que Bergson opõe a dialética da alegria às antinomias da angústia. (PRADO JR, 1988, p. 37-38) 
A pura subjetividade analisada por Bento Prado Júnior no trecho acima é a consciência que segue o fio da experiência, que perde o contato com o real (enquanto o Absoluto) quando efetua recortes da realidade pela percepção, e que acrescenta a essa percepção afecções e lembranças, deformando os dados imediatos da consciência, ou a percepção pura. A aceitação do real e a colaboração de seu engendramento a partir de um observador passivo desempenha o papel da transcendência, fundamental para a experiência da duração filosófica, mais profunda pois é duradoura em um esforço intelectual, que aquela automática que lampeja quando o organismo se encontra em perigo. A intuição filosófica é realçada por um esforço transcendente, de colaboração com a fluidez do real, e de contato com o Absoluto.

\section{1 - Os pseudoproblemas da inteligência}

Precisamos agora aprofundar as duas ordens que compõe o universo bergsoniano e a cosmologia que se constrói a partir de sua compreensão. Uma é a ordem vital, da vida e seus organismos, a outra a geométrica, da matéria inerte e do inorganizado. Nesse sentido podemos dize que a dialética da realidade é entre a vida e a matéria. Como já apontamos, a matéria se dirige rumo a inércia se distendendo no espaço, e a vida é um esforço para retardar a queda da matéria, contraindo o passado no presente e inserindo liberdade na necessidade que caracteriza a ordem física. A vida nesse sentido é um movimento e a matéria é o movimento inverso, e onde o choque do encontro desses movimentos antagônicos gera a organização que são os seres vivos, complexificando suas formas e funções e departamentalizando seus órgãos, em suma, desenvolvendo o sistema nervoso enquanto órgão de gerenciamento entre as volições e as ações. A vida imita a matéria, ou antes se determina por ela em certas direções, adotando, por exemplo, a ordem geométrica e suas características repetitivas que possibilitam nossa inteligência conceituar a partir da generalização, fenômeno vital elementar, pois a vida generaliza em todas as suas manifestações, como no caso da ameba, que permite que determinados elementos adentrem sua estrutura como alimentos, e se devia e evita outras, quando considera perigosas e prejudiciais a si. A própria ordem geométrica da matéria complexificou os organismos, gerando associação em órgãos, desenvolvendo funções, e dividindo grupos e espécies em linhas de evolução divergentes. Duas instâncias requerem diferenciação, a vida, em sentido amplo, como criação e incessante transformação, e os vivos, seus depositários, que repetem determinadas características transmitidas 
hereditariamente embora transformem outras pela união sexuada e pela mutação, levando em frente a tendência criativa o elã vital, produzindo a novidade a cada nova associação entre macho e fêmea.

Segundo Bergson, "as repetições na qual se baseiam as nossas generalizações é essencial na ordem física e acidental na ordem vital" (BERGSON, 2010, p. 254). Uma é a ordem automática, da repetição e do condicionamento entre causas e efeitos, onde o mesmo produz o mesmo, o igual sucede ao igual; e a outra uma ordem "querida" e voluntária da vida. A inteligência não pode compreender esses movimentos antagônicos da dialética do real pois coloca-se no exterior dos objetos que analisa, e quando se depara com uma ordem quando esperava encontrar outra, pensa estar na presença da desordem, e se inunda na incoerência. desenvolvimento de uma teoria genética da inteligência se transforma aqui em uma teoria geral das ilusões do entendimento. Chegamos então à raiz dos falsos problemas que permeiam a teoria do conhecimento, pois os problemas do não-ser, da desordem e do possível ilustram uma ilusão fundamental de um movimento retrógrado do verdadeiro, isto é, como se o existente precedesse a si próprio e projetasse uma imagem de si mesmo como uma mera possibilidade antes de vir a ser efetivamente, como se a ideia de nada possuísse menos conteúdo semântico que a ideia de tudo, ou como se a desordem precedesse a ordem. Porém essa lógica é falaciosa, pois o nada e a desordem possuem mais conteúdo semântico que a ordem ou tudo, e não menos. Isso porque além da ideia de tudo ou de ordem, implicam a negação dessas ideias.

Para Bergson, o problema capital da teoria do conhecimento está em saber como é possível a ciência, isto é, o porquê da ordem e não da desordem nas coisas. Seguindo a argumentação bergsoniana, diremos que a ordem existe de fato e a desordem existe de direito. Mas, quando a ciência procura fundar a ordem, ou o espírito encontrar sentido, é porque se supõe a contingência na ordem vigente, e, "não se pediria nenhuma explicação de uma coisa que não se considerasse contingente" (BERGSON, 2010, p. 255). Porém a ordem é contingente em relação a quê?

Não há o incoerente primeiro, depois o geométrico, depois o vital: há simplesmente o geométrico e o vital, e depois, pelo balançar do espírito entre um e outro, a ideia do incoerente. (BERGSON, 2010, p. 260)

Uma ordem é contingente em relação à outra ordem, e a crítica do negativo de Bergson visa apresentar todas as formas de negação como fontes de falsos 
problemas, pois a contingência é um ponto de vista da inteligência que oscila entre as ordens quando se depara com uma realidade que o decepciona. Assim, entre as duas ordens, a do elã e a do mecanismo, uma está presente quando a outra não está. O erro reside ao fato de que retemos uma ideia geral de ordem sem nos atentarmos para qual ordem estamos a falar, e essa ideia geral de ordem é um misto mal analisado. Por exemplo, unidade e multiplicidade são categorias aplicáveis a matéria inerte, mas o impulso vital não é nem um nem outro, e quando optamos pela unidade ou pela multiplicidade para caracterizar a vida, a opção será instável, e "saltará indefinidamente de uma para outra" (BERGSON, 2010, p. 285), pois a vida nos mostra a mútua tendência tanto para a individualidade quanto para a associação. Mesmo a matéria, se nos esforçarmos intelectualmente para conceber um todo material, é antes um fluxo que uma coisa, e nesse ponto Bergson supera o dualismo, pois a matéria e a vida, holisticamente falando, apresentam a mesma unidade múltipla e multiplicidade una de um todo indiviso (ambas sujeitas à ontologia da duração).

Temos a tendência imanente a pensar em termos de mais e de menos, de ver diferenças de grau ali onde se faz presente diferença de natureza, e pela inteligência o balançar do espírito entre o mais e o menos é inevitável. Precisamos despertar uma tendência crítica para sair dessa gangorra que é a ilusão do nosso pensamento, preso entre a ordem voluntária ou "querida" da vida e a ordem automática e mecânica da matéria. A intuição seria essa tendência crítica para combater a ilusões fundamentais do entendimento e comunicar à inteligência as diferenças de natureza que se havia concebido equivocadamente como diferenças de grau. Nesse sentido a inteligência seria a faculdade de colocar problemas em geral, e o instinto da intuição encontraria soluções, isto é, a intuição poderia se decidir acerca do verdadeiro e do falso e comunicar a decisão à inteligência.

[...] a intuição é o próprio espírito e, em certo sentido, a própria vida: a inteligência é recortada nela por um processo imitativo daquele que originou a matéria. Surge assim a unidade da vida mental. Para a reconhecer é necessário que nos instalemos na intuição, para ir dela à inteligência, pois que da inteligência nunca se passará para a intuição. (BERGSON, 2010, p. 292)

Por ser fruto adaptativo, a inteligência se desenvolveu para resolver os problemas das práxis e limita-se a esta destinação primitiva. Na práxis o organismo encontra-se sempre eminentemente em perigo: a fome o espreita, a doença e a velhice são iminentes. Nesse sentido, quando o ser humano encara a realidade com o olhar da inteligência, interpreta o real visando transformar esse real numa 
configuração favorável, dada a memória que dota o indivíduo com gosto e desgosto, vontade e receio, em relação a objetos determinados. Enquanto utilizada para agir sobre a matéria a inteligência é útil e indefinidamente poderosa, pois como mostramos, é uma forma sem conteúdo, como o conceito abstrato da linguagem. As ferramentas manufaturadas pela inteligência podem ser utilizadas para uma infinidade de aplicações, pois inteligência e matéria adaptaram-se uma à outra, e a ordem natural do nosso pensamento compartilha as mesmas determinações genéricas em que a matéria se distende no espaço. A supraconsciência que Bergson anuncia no terceiro capítulo do livro, entendida como consciência em geral e coextensiva à vida, é o rojão cujos destroços caem como matéria, e a consciência carregada de materialidade é o que subsiste do próprio rojão "atravessando os destroços e iluminando-os em organismos" (BERGSON, 2010, p. 285).

\begin{abstract}
A inteligência, segundo Bergson, tem dois aspectos correlativos, que formam a ambiguidade que lhe é essencial: ela é conhecimento da matéria, ela marca nossa adaptação à matéria, ela se amolda à matéria, mas ela só o faz à força de espírito ou de duração, à força de inserir-se na matéria em um ponto de tensão que lhe permite dominá-la. Na inteligência, portanto, devem-se distinguir a forma e o sentido: ela tem sua forma na matéria, ela encontra sua forma com a matéria, isto é, no mais distendido, mas ela tem e encontra seu sentido no mais contraído, pelo qual ela domina e utiliza a matéria (DELEUZE, 1999, p. 71)
\end{abstract}

A partir daqui, com a ajuda de Deleuze, podemos compreender a forma da constituição do conhecimento, pois a realidade, que adota uma estrutura de uma das duas ordens, guia as determinações de nosso pensamento embora sempre utilize a tensão característica da vida para atualizar uma ação a partir da virtualidade da memória. Para pensar a matéria a inteligência exterioriza-se de si, porém não completamente, pois opera a partir da experiência passada, de onde deduz e induz, contraindo o passado para encontrar uma solução útil no presente. A inteligência foi cunhada no processo evolutivo para pensar a ordem geométrica da matéria inerte pois adaptou-se mirando à matéria, mas é essencialmente incapaz de acessar a ordem vital, pois opera exteriorizando-se, fragmentando o devir em instantes, e quando encara o vivo, o encara com as mesmas vestimentas que utiliza para pensar o inorgânico. Isso porque mesmo com a ilimitada desenvoltura a agir sobe o inerte, a inteligência não pode compreender seu habitáculo: a consciência duracional aonde opera e projeta seus pensamentos fixistas. A matéria como o grau mais distendido do impulso originário é a própria forma da inteligência, que a imita distendendo-se na espacialidade através da materialidade das palavras. Portanto, embora cunhada para 
manipular o inerte, a inteligência só consegue obter sucesso ao manipular o passado, isto é, a inteligência só ganha o domínio sobre a matéria quando contrai a memória na situação presente. Esse plano da tensão que gera a contração, que é o sentido do espírito e do esforço, está presente na inteligência e deve ser reencontrado pela intuição. A conclusão da gênese simultânea da matéria e da inteligência e sua adaptação recíproca é extraída do fato de que a inteligência se contrai na matéria enquanto a matéria se distende na duração, e ambas se acomodam no extenso, encontrando no espaço puro um ponto em comum.

[...] se, quando especularmos sobre a natureza do real, continuarmos a encará-lo da maneira que o nosso interesse prático nos convida a fazê-lo, então seremos incapazes de ver a verdadeira evolução, o devir radical. Do devir só captamos estados, da duração apenas instantes, e até quando falamos da duração e do devir é em outra coisa que estamos pensando. (BERGSON, 2010, p. 298)

A inteligência, no entanto, possui em potência a possibilidade de distender-se mais que a própria matéria se distende no espaço como extensão, isto é, a inteligência se distende conceitualmente num espaço puro. Essa operação concebida pela inteligência torna possível ao homem reencontrar todos os graus de distensão e contração que coexistem no todo atual e virtual. A tendência à conceptualização e à cristalização da palavra imita e segue a tendência à distensão da matéria inerte, mas o homem possui em potência a possibilidade de perscrutar os mais distantes graus de distensão e seguir retroativamente o elã da vida até a origem do impulso vital, porém essa tendência raramente é atualizada, pois a inteligência operando por suas tendências naturais, acomoda-se no mais fácil, e não leva adiante sua liberdade. Devido à alta complicação de seu cérebro, o homem alcançou um privilégio perante as outras espécies, e nele a liberdade encontra livre atualização. Bergson se esforça para mostrar que ciência e metafísica possuem destinação diferentes e objetos distintos, devendo, no entanto, auxiliarem-se uma à outra. O homem, fragmentando o devir em conceitos e objetos a partir da inteligência, precisa se reconectar com a intuição para conhecer a si mesmo na vida como elã (ou consciência em geral) de que faz parte. Bergson procura evidenciar uma confusão que permeia a filosofia desde os gregos antigos até a contemporaneidade, a saber, a confusão que nasce ao transferir os esquemas da práxis (da inteligência e das suas ferramentas) ao exercício da contemplação. A metafísica deve renunciar às ferramentas da inteligência para estabelecer-se na própria fluidez da realidade, sendo a própria extensão da matéria apenas uma representação mental de uma realidade mais profunda onde tudo é 
vibração e movimento (novamente onde o monismo supera o dualismo na filosofia de Bergson).

Percorrer os caminhos do equívoco da inteligência indica a própria estrutura do espírito, e no capítulo quarto de Evolução Criadora Bergson reconstrói uma história da filosofia desde os gregos, e evidencia os equívocos dos mecanismos da inteligência na filosofia e na ciência. Segundo Bergson, um erro acompanhou todos os sistemas e teorias clássicas e modernas, o erro proveniente do mecanismo cinematográfico do pensamento, que constrói o movente a partir de imobilidades, e que procura criar o movimento a partir da reunião de instantes justapostos, como procede o rolo cinematográfico, onde tudo está dado, e onde o tempo é reduzido a velocidade com que o mecanismo trabalha e faz as imagens se justaporem projetadas na tela. É nesse mecanismo que opera tanto o pensamento ordinário do senso comum como a ciência positiva, e duas ilusões subjazem ocultas como fundamento de ambas.

A primeira ilusão, já anteriormente apresentada, é a ilusão proveniente de pensar o devir a partir de imobilidades, formando propriamente o que Bergson denomina de mecanismo cinematográfico da inteligência, metáfora oriunda do cinema nascente da época de Bergson, onde a película de filme projeta o movimento a partir da justaposição de vinte a trinta quadros por segundo. Segundo Bergson, desde a antiguidade essa ilusão fundamental foi formulada por Zenão de Eléia, onde o movimento é decomponível em instantes, e tomando o exemplo de uma flecha, poderíamos dizer que ela se encontra imóvel em cada um dos instantes do trajeto que percorre. Da mesma forma, em uma corrida disputada por Aquiles e uma tartaruga, e dada uma vantagem à tartaruga na largada, Aquiles nunca iria ultrapassá-la, pois dividindo os instantes de maneira homogênea, sem levar em conta a diferença qualitativa entre os passos de Aquiles e os da tartaruga, quando Aquiles terminasse um passo, a tartaruga já teria dado outro, e quando Aquiles, então, desse mais um passo, a tartaruga teria acrescentado mais outro, mantendo a vantagem inicial da largada infinitamente.

É justamente essa concepção de movimento que Bergson quer derrubar, pois é esta ideia que permeou a filosofia antiga e a metafísica clássica, e que se manteve oculta nos postulados da ciência mecanicista mesmo quando esta pretendeu pensar o vivo e o psicológico. Para Bergson não podemos dizer que a flecha se encontra estável em nenhum dos momentos de seu trajeto, da mesma forma que é obvio que Aquiles rapidamente ultrapassaria a tartaruga em uma disputa de velocidade. $\mathrm{O}$ movimento é indecomponível, salvo de maneira retrospectiva em um esforço de 
abstração, recortando o movimento do todo em que faz parte e construindo assim um sistema relativamente fechado. A ciência procede a partir de tais recortes e concebe o movimento abstraído do todo de maneira retrospectiva, possibilitando a fragmentação indefinida do tempo em quantos estados fixos lhe aprouver. Porém, cabe novamente ressaltar, esses métodos não cabem no movimento evolutivo e psicológico que os transborda, e onde cada instante está em germe no anterior, e o presente carrega em si todo o passado de maneira virtual.

Contrariamente à ontologia clássica que reduz o devir à imobilidade e a uma eternidade inerte, a experiência nos ensina que a realidade sensível é a presença de um devir, mas os antigos, ao conceber uma realidade inteligível mais real que a realidade percebida pelos sentidos, imaginaram que esta realidade superior não muda. O intelecto, segundo Bergson, pretende pensar o devir experimentado pelos sentidos de três formas: um devir qualitativo, um devir evolutivo e um devir extensivo. "O espírito deve procurar aquilo que é refratário à mudança: a qualidade definível, a forma ou essência, o fim. " (BERGSON, 2010, p. 342). Para Bergson essa é a filosofia que se desenvolveu na antiguidade clássica, e a palavra grega Eidos, fundamental no pensamento antigo, designa em primeiro lugar uma qualidade, em segundo uma essência, e em terceiro uma finalidade ou o desenho do ato suposto realizado. Esse triplo sentido corresponde as três categorias essenciais da linguagem: o adjetivo, o substantivo e o verbo.

[...] eidos é a visão estável da instabilidade das coisas: a qualidade, que é um momento do devir; a forma, que é um momento da evolução [...] e por fim o desígnio, inspirador do ato realizando-se, o qual não é mais, dizíamos nós, que o desenho antecipado da ação realizada. Reduzir as coisas às Ideias consiste, portanto, em resolver o devir nos seus momentos principais, sendo, aliás, cada um destes subtraído por hipótese à lei do tempo e como que colhido na eternidade. $\mathrm{O}$ que significa que se chega à filosofia das Ideias quando se aplica o mecanismo cinematográfico da inteligência à análise do real. (BERGSON, 2010, p. 343)

A forma (ou eidos) é isolada do devir, são momentos colhidos ao longo da duração e armazenados em um conceito. Dessa forma é cortado o fio que as ligava ao tempo e cristalizam-se na eternidade. Mas, para Bergson, aquilo que têm de eterno corresponde àquilo do que tem de irreal. Portanto, as formas concebidas através do mecanismo cinematográfico do pensamento deixam de ser visões da mudança das coisas, e representam aquilo que é positivo no devir, isto é, assimiláveis em formas fixas e passíveis de generalização, mas a essência, se podemos falar em essência, é a tendência da forma em mudar, e não as características positivas que a percepção recorta nas coisas. Para os antigos essas formas eternas não são apenas abstrações 
da inteligência, mas fundamentam a realidade e constituem e escopo do real. Também uma concepção de extensão é implicada pela filosofia das Formas dos gregos antigos. Logicamente concebemos que toda forma ocupa espaço da mesma maneira como ocupa um momento no tempo, mas, segundo Bergson, a filosofia das ideias segue o caminho inverso, pois não concebe a forma por intermédio de uma experiência sensível da duração e da mudança, mas as tira do eterno, resultando que a duração e o devir seriam degradações da eternidade imóvel. A forma como conceito cristalizado não é mais a forma apreendida por uma percepção sensível, e é o estatuto desta percepção que Bergson procura recuperar.

A metafísica de Bergson é fundamentada por um empirismo rigoroso, e na base desse empirismo reside a necessidade prática da ação de sobrevivência do organismo perante o meio. O que leva o organismo a agir é uma necessidade de sanar uma falta. Existe aqui uma ausência real que gera, entretanto, uma miragem da Ausência em sentido amplo. A necessidade que o organismo sente - a fome, a sede, o frio movimentam o ser a agir para preencher uma ausência na forma de necessidade física; esse fato conduz Bergson à constatação de que a práxis é a produtora do negativo, devido a experiência da carência. Essa é a raiz antropológica da ilusão da Ausência em sentido amplo, denunciada por Bento Prado Júnior em Presença e Campo Transcendental. O problema está no momento em que aplicamos à especulação este mesmo procedimento utilizado na ação, passando da ideia do vazio ao pleno, da ausência à presença e do possível ao real. Nessa passagem nascem os pseudoproblemas que macularam os sistemas filosóficos da antiguidade e da ciência moderna. Porém, quando constatamos a existência de pseudoideias como base de problemas metafísicos, é natural que os classifiquemos como pseudoproblemas, e, portanto, deixam de ser um problema assim que identificamos sua gênese como misto mal analisado. A origem dos falsos problemas reside antes na dificuldade de encontrálos do que na de resolvê-los, e dessa forma, os problemas da especulação seriam resolvidos assim que devidamente colocados. Ao perceber o problema ele se desfaz, e, embora seja a solução que importa, ela depende de como foi colocada a questão.

\footnotetext{
Um problema se determina ao mesmo tempo em que é resolvido; mas sua determinação não se confunde com a solução: os dois elementos diferem por natureza, e a determinação é como que a gênese da solução concomitante. (DELEUZE, 2009, p. 154)
}

Esta ilusão está intimamente aparentada com aquela já referida sobre a questão das duas ordens e o misto mal analisado referente à desordem e ao caos, 
que são ideias práticas, e que correspondem a uma decepção de uma determinada expectativa, não a constatação da ausência de toda e qualquer ordem, mas apenas a presença de uma ordem que não interessa de forma nenhuma. Como nos alerta Bergson, aquilo que se percebe é sempre a presença de alguma coisa, nunca a ausência seja do que for. "Só existe ausência para um ser capaz de recordar e de esperar" (BERGSON, 2010, p. 307), isto é, a ausência surge quando a consciência permanece atada à lembrança de um estado anterior, mas quando já está presente um estado novo.

\begin{abstract}
A representação do vazio é sempre uma representação plena, que após analisada se resolve em dois elementos positivos: a ideia, distinta ou confusa de uma substituição e o sentimento experimentado ou imaginado de um desejo ou de uma saudade (BERGSON, 2010, p. 309)
\end{abstract}

A partir da ideia de nada Bergson critica os postulados da tradição filosófica que se fundamentou na miragem da Ausência e pode ser considerada uma filosofia do negativo. A crítica da ideia de nada é a desmistificação da filosofia tradicional a sua pretensão de radicalidade, como, por exemplo, a dúvida hiperbólica de Descartes, que ilustra essa pretensão à radicalidade que eliminaria existência a tudo aquilo que gerasse dúvida. Porém, defende Bergson, pela supressão intelectual de todas as coisas não chegamos à ideia de nada, diferentemente da operação inversa, onde pela adição intelectual de todas as coisas podemos conceber a ideia de tudo. É a imaginação do negativo que está na origem da questão "angustiante": porque há o Ser, e não apenas o Nada? A partir da constatação e consequente dissolução da miragem da ausência, o próprio ser da duração se torna acessível, e a consciência se instala na presença. Em um primeiro momento pode-se conceber que a utilidade prática imediata advém apenas com a maneira cinematográfica de proceder e se inserir na materialidade, mas com a metafísica e o conhecimento íntimo do real, isto é, da ontologia da duração, pode-se dar uma virada qualitativa, pois compreendendo a essência psicológica do real, da duração como escopo de tudo, dissolve-se a angústia da existência consequente da miragem do vazio. A metafísica, como nos alerta Bergson, busca a felicidade, enquanto a ciência nos possibilita a sobrevivência. Segundo Bento Prado Júnior:

[...] a subjetividade da consciência - a práxis humana - não pode permanecer apenas oposta à objetividade do Ser. Pois é através de uma subjetividade que o ser pode tornar-se presente. A Presença, em geral, só pode ser compreendida à luz de sua tripla determinação: ela supõe não apenas aquilo que se torna presente, mas indica também alguém a quem o que é presente se dá como tal. Mais ainda, a presença supõe, para além do "algo" e do 
"alguém", um "lugar" onde algo se torna presente para alguém. Isto é, a Presença só se dá no interior de um campo transcendental que a torna possível. (PRADO JR, 1988, p. 68)

Esse campo transcendental se dá em torno de um sujeito cognoscente. Somente um sujeito que se apodera das circunstâncias que o rodeia, que se instala de maneira neutra e passiva ao contemplar a realidade de que faz parte, é capaz de atingir um campo transcendental e experienciar a duração íntima do real. Esse campo é acessível à consciência humana com a descoberta de um modo de percepção primitivo e indiferenciado, onde a intuição nos instala em uma imagem geral da vida. Essa duração originária é a região onde as contradições do entendimento são superadas, e onde o problema da consciência se transforma no problema de sua gênese e sua resolução concomitante. De onde podemos dizer, portanto, que a inteligência possui vocação estabilizadora, mas para Bergson, a filosofia deve furtarse ao conceito, essencialmente estabilizado e cristalizado em significado. Conceituar e reificar são os papeis da ciência positiva, e a filosofia, e propriamente a metafísica, enquanto ocupam-se com a duração e pretendem despertar a intuição, devem se manter alertas para não se cristalizarem em coisa e conceito; a densidade das palavras deve ceder lugar ao ritmo do pensamento que salta de imagem em imagem.

Para transmitir a intuição precisamos trocar a cristalização simbólica do conceito pela expressividade mutável das imagens "que no movimento de flutuação de seus significados fazem o espírito dirigir a atenção reflexiva para o ponto onde se poderá intuir uma realidade." (LEOPOLDO, 1994, p. 106). A linguagem deve ser aqui entendida fundamentalmente como um obstáculo para a transmissão da intuição, e a filosofia deve preocupar-se de que o discurso não solidifique ou cristalize a impressão, isto é, deve apenas produzir a impressão ou sensação da passagem e do movimento. A metáfora então, é o caminho encontrado por Bergson para transmitir o movimento da duração e, portanto, despertar a intuição. Como nos alerta Franklin Leopoldo:

\footnotetext{
A palavra não reproduz movimento, mas o estilo pode sugerir a mobilidade. Não são só as imagens de que a expressão se constitui que sugerirão o que se quer exprimir, mas o discurso enquanto tal deve ser uma metáfora do movimento (1994, p. 110).
}

A filosofia deve se colocar como o conhecimento sub specie durationis, isto é, deve recuperar a impressão imediata, invertendo o papel da linguagem que é justamente a permanência do significado. A presença da linguagem é um impedimento para o contato imediato com a coisa, mas também é única ferramenta de se fazer ciência e 
transmitir riqueza ao espírito pela filosofia. A arte e a linguagem metafórica desempenham aqui o papel de inversão da função cristalizadora da linguagem, procurando transmitir não um significado de uma coisa, mas uma imagem fluída de um movimento também fluído.

Como, para Bergson, o conhecimento é sempre relacionado com gêneros e leis, precisamos colocar em questão o problema das ideias gerais, que está na raiz mesma do fundamento do conhecimento, na medida em que a identidade e a semelhança são fatores da inteligibilidade do real. É no plano biológico e não no lógico que encontramos a origem da faculdade de generalizar, encontrada tanto em nós, humanos, quanto em outros animais. É o caso de um macaco, que a partir de uma determinada tonalidade do verde, generaliza que é uma folha apetitosa e nutritiva. Mais elementarmente, e estendendo essa capacidade para a vida em geral, podemos dizer que até mesmo os tecidos do ser vivo generalizam, pois, generalizar é a atividade que permite a troca gasosa e de nutrientes "queridos" pelo organismo com o meio ambiente. Generalizar pode ser pensado como extrair semelhanças, e é o fundamento da representação vivida. Porém entre o estágio elementar de generalização da representação vivida pela vida em geral, e a nossa, isto é, a generalização reflexiva e intencional, encontramos uma camada intermediária estabelecida pelo hábito como um acréscimo do instinto. A base comum da generalização é aquela em que as necessidades de sobrevivência impõe ao organismo vivo, em todas as suas manifestações, mas só o homem a utiliza em uma intencionalidade refletida, nos abrindo a possibilidade de generalizar para além do âmbito pragmático da sobrevivência. O hábito é a camada intermediária entre a faculdade de generalizar comum à vida em geral e a generalização espiritual própria dos seres humano (e apenas de alguns entre nós), e este hábito, como a cristalização das palavras, cristaliza respostas em estímulos e influência a percepção à determinados contornos. Apenas quando a generalização escapa dos grilhões da necessidade prática que a relação entre o sujeito e o mundo torna-se instrumento de conhecimento.

Porém, para compreendermos o caráter desinteressado da intuição como generalização livre do pragmatismo, precisamos analisar a faceta espiritual da generalização, em oposição ao seu oposto material do hábito, estabelecido a partir da identidade de reações apreendidas e analogia dos estímulos recebidos. Porém como escapar à linguagem nesse processo desinteressado? É por ela e seus símbolos que condensamos a diversidade, tornando o real inteligível para a inteligência e passível de ser transmitido para outros sujeitos. 
Mas, por ser uma referência geral, a palavra logo obscurece nela mesma a pluralidade dos seus significados originários, e passamos a entender a multiplicidade do que nela é referido quase como se fosse uma coisa, passando a inexistir na prática a diferença entre a unidade do termo e a pluralidade do real (LEOPOLDO, 1994, p. 88)

Essa reificação do conceito (originalmente múltiplo pois designa um gênero), é o que permite a generalização deliberada, e quando se torna reflexão, a generalização abre espaço para uma ação espiritual, pois é pelo esquecimento dessa multiplicidade e pluralidade do real - esquecimento que condensou a coisa em palavra - que criamos um conteúdo inteligível para o pensamento. Devemos então desvincular a generalização do empírico para conceber uma generalização espiritual. O mundo prático se caracteriza justamente pelo ocultamento da totalidade, interrompendo a duração e cristalizando estados e paradas. Portanto, qualquer fixação e cristalização da realidade em conceitos é uma limitação do movimento. Similarmente, os organismos são como que cristalizações residuais, verdadeiros depositários da realidade que é movimento orgânico e indivisível. "Assim como o pensado é cristalização do pensamento, o organizado é cristalização do movimento organizador. " (LEOPOLDO, 1994, p. 245). Dessa forma chegamos a questão da identificação do pensamento com o pensado, da mesma maneira que o elã criador das formas está sempre diante de formas já criadas. Essa identificação é uma limitação da consciência empírica, fragmentada do todo e identificada com os condicionamentos de seu caráter e experiências de seu passado. A consciência pessoal, egoica e subjetiva, é o eu-superficial analisado nos Dados imediatos da consciência. O Eu-profundo é a consciência reabsorvida no elã criador, é a consciência coextensiva à vida, que liga todos os organismos em uma virtualidade real.

A preocupação de Bergson indica uma necessidade premente da sociedade para desenvolver a felicidade nos indivíduos que a compõe. A inteligência, quando deixada à deriva como a única forma de viver e experienciar à realidade é fonte de patologias psíquicas que assombram a mente dos indivíduos, pois os desconecta do todo, os privam de experienciar a plenitude da vida que significa e enriquece a existência. A intuição como método de descobrir os falsos problemas que infligem o pensamento, é um conhecimento urgente a ser ensinado e desenvolvido, dado que coincidir consigo mesmo é coincidir com todos que vivem na mesma comunidade, contribuindo para a harmonização social individual do eu consigo mesmo. A análise como forma de abordar o real é inquestionável, dado o alcance da indução e da 
dedução nas conquistas da ciência e da tecnologia em desenvolvimento vertiginoso. A inteligência é indefinidamente poderosa para pensar e manipular a matéria inerte, mas inadequada para abordar os fenômenos de ordem psíquica. Sofremos hoje dos males que sofriam antigamente nossos antepassados, mas intensificou-se a angústia na sociedade superpopulosa em que vivemos e onde o tempo (espacializado) se acelerou pela quantidade de informação e pelas demandas que nos rodeiam pelas novas tecnologias de comunicação. Aprendemos desde pequenos a deduzir, induzir, comparar e analisar, porém não nos ensinam a viver a duração de nossa vida psicológica, que é a duração da vida e do universo sempre pleno de significados. Essa fragmentação do todo é obstáculo a ser superado, e viver em duração, para além do conceito e da palavra, é matéria a ser ensinada para o bem viver, assim como as ciências são transmitidas e desenvolvidas para garantir a sobrevivência a novos obstáculos. "A ciência nos oferece o prazer, no máximo o bem-estar, mas apenas a filosofia pode nos oferecer a alegria. " (BERGSON, 2006, p. 148). Após delinear brevemente a concepção bergsoniana de filosofia e dado o nobre objetivo a ela consagrado, precisamos analisar a intuição como método, pois é por ela que Bergson acredita restituir a felicidade e a plenitude à consciência humana.

O vício das teorias do conhecimento foi sempre o de estabelecer diretamente a estrutura dos procedimentos gnosiológicos como se o espírito fosse separado ou separável do contexto material em que se encontra, das necessidades inerentes ao ser vivo (LEOPOLDO, 1994, p. 85)

O conceito de intuição desempenha papel fundamental no bergsonismo, sendo a chave para a distinção entre filosofia e ciência. Aqui o principal interlocutor de Bergson é Kant e seu uso do termo intuição para caracterizar uma certa limitação do sujeito cognoscente, dado que no kantismo tempo e espaço são formas da nossa intuição sensível e condições subjetivas e necessárias de toda experiência empírica e psicológica. Portanto espaço e tempo são para Kant formas puras a priori da intuição. Isto é, nós conhecemos o mundo a partir dessas duas categorias de espaço e tempo, e as causas de nossas sensações são exteriores à nós, mas nós não podemos conhecer essas causas através de nenhuma abordagem sensória. Tempo e espaço são as próprias condições da receptividade dos sentidos, sem essas categorias não perceberíamos. Kant estabeleceu que a extensão no espaço e a existência no tempo não são propriedades que pertencem as coisas, mas propriedades de nossa sensibilidade. Portanto, percebendo as coisas pelos sentidos nós instalamos sobre a coisa em si as condições de tempo e espaço como formas da 
nossa percepção. A diferença entre Bergson e Kant é traçada no quesito tempo, que para Kant é uma forma pura interna do sujeito que experiencia a realidade, enquanto para Bergson o tempo é uma duração qualitativa e heterogênea da experiência vivida e da realidade em geral, e não apenas uma categoria de nosso intelecto. Enquanto em Kant o sujeito experiência o tempo sempre sob a forma subjetiva da nossa intuição, sempre sensível na medida que somos afetados pelos objetos via sensibilidade, e nunca acessamos o "em si", apenas o "para nós", para Bergson o tempo é uma propriedade real das coisas e do universo, e Kant, segundo Bergson, apenas concebeu o tempo especializado pelo intelecto, e não à duração íntima do real. Para Bergson a intuição é justamente a possibilidade de acessar o em si das coisas, coincidir com os objetos em sua forma sem as construções teóricas da inteligência e sem a cristalização conceitual da palavra. Inicialmente intuição é sentir o objeto em si mesmo, afastando-nos do para nós com a carga afetiva do passado conceitual do sujeito cognoscente.

Intuição e tempo são termos semelhantes, e para erigir uma metafísica positiva em torno da ideia de intuição é necessário se desvencilhar dos modernos, onde o tempo é definido em termos de espaço. Como já apontamos, esse tempo espacializado oriundo dos cortes instantâneos do mecanismo cinematográfico do real é insuficiente para representar a experiência vivida do real. Intuição é, portanto, intuição da duração, inserção no tempo real que flui indivisível. A consequência do raciocínio de Kant é afirmar a relatividade do conhecimento humano dado que nos nega a apreensão da coisa em si, porém afirma que todo conhecimento deve necessariamente partir de conceitos de contornos definidos para agarrar com eles a realidade movente do real. Bergson irá seguir por outra via, defendendo a possibilidade de apreensão do real na imediaticidade da percepção sensível.

\subsection{A intuição como método}

A intuição é o método do bergsonismo. A intuição não é um sentimento nem
uma inspiração, uma simpatia confusa, mas um método elaborado, e mesmo
um dos mais elaborados métodos da filosofia. (DELEUZE, 1999, introdução)

Filosofar requer que se violente ou inverta o sentido da operação pela qual habitualmente pensamos. Essa inversão da direção do trabalho do pensamento ordinário é o posicionamento da atenção no sentido da realidade móvel, violentando a tendência analítica que a sociedade constrói em nós de encarar o real com conceitos rígidos e já feitos através da inteligência. Podemos dizer que a filosofia possui um 
objeto determinado: seu objeto é a temporalidade absoluta, o ser da duração. O trabalho bergsoniano de pensar a evolução da vida é voltado para demonstrar a insuficiência dos conceitos já feitos em reconstituir a realidade viva como um todo indiviso; seu esforço está em demonstrar o fracasso das ciências exatas em abordar o domínio da vida e do psicológico e em restituir o homem na totalidade do real, do orgânico com o inorgânico e do espaço com a duração.

\footnotetext{
Flower in the crannied wall,

I pluck you out of the crannies,

I hold you here, root and all, in my hand,

Little flower - but if I could understand

What you are, root and all, and all in all,

I should know what god and man is. ${ }^{1}$
}

Esse poema de Tennyson pode nos ajudar a compreender a inteligência, pois ilustra a abordagem do intelecto perante o a vida e o universo. Para conhecer a flor, o observador a arranca, a mutila e a mata para sanar uma necessidade de conhecer imanente à inteligência; mas, nesse processo de conhecimento, fragmenta o real para analisá-lo, com a vã pretensão de compreender o vivente depois de tê-lo matado. A medicina é muitas vezes estudada desta maneira, isto é, pela dissecação dos corpos. Metodologia esta que perde de vista a energia que anima o organismo, e, consequentemente, a harmonia de conjunto que trabalha enquanto o corpo goza de saúde. Estudar um organismo morto é qualitativamente diferente de estudá-lo vivo. Uma função vital para o funcionamento do conjunto pode sumir quando a energia que anima o corpo se dissipa, e dessa forma, o conhecimento obtido por esse procedimento é limitado. Conhecer e filosofar acontece de maneira imediata com o objeto, e, segundo Bergson, é a experiência da mudança o próprio conhecimento dito espiritual. O observador do poema pretende conhecer tudo, Deus e a vida, porém destruindo o movimento natural da coisa, interrompendo o ímpeto vital que a anima. Procura por Deus a partir do intelecto, pela análise e pela dissecação do real. O conhecimento da vida, segundo Bergson é de ordem contrária a inteligência. observador dotado de intuição se colocaria em frente a flor de forma que não interrompesse seu movimento, sendo o próprio movimento que buscaria captar ao observa-la sem destruí-la.

\footnotetext{
1 "Flor na muralha fendida, / eu colho-te das fendas, / seguro-te aqui, raiz e tudo, na minha mão, / pequena flor... mas se eu pudesse compreender / o que tu és, raiz e tudo, e tudo em tudo, / eu deveria saber o que Deus e o homem é." Alfred, Lord Tennyson em "Poemas de Alfred Tennyson". Tradução Octávio Santos. Lisboa: Editora Saída de Emergência, 2009.
} 
Intuição deve ser entendida aqui como a função metafísica do pensamento, o conhecimento íntimo do espírito pelo espírito e daquilo que há de essencial na matéria. A inteligência procura conhecer as relações que se apresentam a nós pelos sentidos no mundo fenomênico, mas não é destinada para pensar o "fundo das coisas", isto é, em mergulhar profundamente no significado da vida. Aparentemente contrárias, intuição e inteligência quando trabalhando juntas numa filosofia verdadeiramente intuitiva levaria as ciências positivas a tomar consciência de seu verdadeiro alcance e a impulsionaria a descobertas mais profundas. Bergson não priva a inteligência neste processo, mas quer introduzir à inteligência depois de ter estabelecido a intuição, consistindo em uma inteligência restituída a sua posição de direito, como uma ferramenta a ser utilizada na análise, quando os problemas são colocados pela intuição. Uma filosofia intuitiva, positiva, realizaria a união entre metafísica e ciência e "colocaria mais metafísica na ciência e mais ciência na metafísica. " (BERGSON, 2006, p. 224).

A filosofia clássica pode ser sumarizada em um princípio que Bergson formula assim: "Há mais no imutável do que no movente e passa-se do estável para o instável por uma simples diminuição. "Segundo Bergson é o inverso que é verdadeiro (BERGSON, 2006, p. 225). Bergson concebe três espécies de atos para caracterizar a intuição como método: o primeiro referente à criação de problemas (e a consequente identificação de falsos problemas), outro referente à descoberta das diferenças de natureza que subjazem nos mistos mal analisados da inteligência e da percepção carregada de memória, e o último, onde se instala a intuição da duração, pela apreensão do tempo como heterogeneidade contínua, ou seja, duração.

Os falsos problemas são de dois tipos, os inexistentes e os mal colocados. Os inexistentes são aqueles da desordem, do não-ser, do caos e do possível, e os mal colocados são aqueles concernentes as querelas da liberdade e da intensidade dos estados psicológicos, e são responsáveis pelo agrupamento em uma mesma categoria de coisas que diferem por natureza, como o prazer e a felicidade. A intuição procede como um verdadeiro método de divisão, separando o que é um misto de elementos de naturezas diferentes.

Segundo Deleuze, a intuição forma um método problematizante, diferenciante e temporalizante. Problematizante na medida que efetua a crítica dos falsos problemas e cria verdadeiros, diferenciante na medida em que é um método de divisão levando em conta as articulações qualitativas do real, e temporalizante enquanto exige que pensemos em termos de duração. E, embora o bergsonismo esteja repleto de 
dualismos, pela intuição Bergson os supera e instala no lugar um monismo de um tempo único. Aqui precisamos compreender a questão do atual e do virtual, e a noção de virtual precisa adquirir precisão conceitual.

Sabemos que o virtual, como virtual, tem uma realidade; essa realidade, estendida a todo o universo, consiste em todos os graus coexistentes de distensão e de contração. Gigantesca memória, cone universal, onde tudo coexiste com tudo com maior ou menor diferença de nível. (DELEUZE, 1999, p. 80)

O virtual é algo simples que se atualiza, é a tendência mesma de diferenciarse em tendências divergentes. A duração é o próprio virtual, e a distensão da matéria e a contração da vida demonstram essa tendência à diferenciação. Na esfera psicológica vemos que o passado possui existência positiva enquanto coexiste com o presente, e nesse sentido o passado é o virtual que se atualiza de forma simples, dado uma percepção consciente ou um estímulo inconsciente. Bergson censura a metafísica por ela ter concebido distensão e contração como graus mais ou menos intensos na degradação de um mesmo Ser estável e eterno. Como nos lembra Deleuze:

Não há no princípio um ser imóvel e estável; aquilo de que é preciso partir é
a própria contração, é a duração, da qual a distensão é a inversão. [...] Por
que é a distensão o inverso da contração, e não a contração o inverso da
distensão? Porque fazer filosofia é justamente começar pela diferença, e
porque a diferença de natureza é a duração, da qual a matéria é somente o
mais baixo grau. A diferença é o verdadeiro começo; (DELEUZE, 1999, p.
122)

A diferença como verdadeiro começo remete ao espírito como elã vital, o espírito ou esforço que cria as formas em atos indivisíveis. O espírito é a ação da duração, ação do tempo. Dessa forma, o agente ontológico fundamental é a natureza psicológica da causa originária, gerando a distensão da matéria e a contração da vida. A hipótese do nada como agente ontológico é a raiz das ilusões, o imutável a causa originária e a semente dos equívocos da metafísica. Se há um absoluto ele é propriamente ação. A consciência empírica age por negação, e a carência a induz a agir, mas a supraconsciência, ou a própria totalidade, age por criação. A consciência empírica ou subjetiva nos conduziu à constatação de sua intrínseca incompletude reflexiva, e a intuição jorra subjetivamente como um anseio de plenitude. A consciência é muito mais ampla que a subjetividade, e realizar plenamente a reflexão é atingir a consciência coextensiva à vida a partir da experiência da temporalidade 
subjetiva, interna do sujeito. Nesse processo efetua-se uma ampliação da experiência e um enriquecimento da subjetividade através da consciência da temporalidade absoluta. Através da intuição a parte é reabsorvida no todo e o sujeito coincide com o absoluto. 


\section{Conclusão}

A partir do presente estudo delineamos o objeto próprio da filosofia e esboçamos a abordagem intuitiva de análise do real. Essa abordagem visa a reabsorção do indivíduo na totalidade da vida e do cosmos, restituindo a plenitude que vemos presente em todos os seres vivos salvo no ser humano. Dentre as espécies, apenas o homem vive em angústia, sendo a carência sua norma e o prazer sua meta. A intuição como simpatia nos aproxima da constatação que conhecimento e autoconhecimento estão intimamente ligados, e a separação entre interioridade e exterioridade é superada apenas por certa ontologia da subjetividade do sujeito.

O método cinematográfico do real representa a incompletude reflexiva da consciência empírica, que opera no mundo esquecida de si, e pensa à vida com os conceitos talhados para pensar o inerte. $O$ cinema como produtor da ilusão do movimento é uma metáfora precisa de Bergson para ilustrar as ilusões da inteligência, pois o movimento que produz é elementarmente formado por instantaneidades. Porém o cinema, como todas as artes, desempenha um papel importante para transmitir a intuição do movimento vital. Em 1907, quando A Evolução Criadora foi lançada, o cinema era um protótipo do que é hoje, e as técnicas narrativas que utiliza, tão comuns para a sociedade contemporânea, ainda não haviam sido inventadas. O cinema era mudo e não haviam cortes. Dessa forma a projeção das imagens justapostas transmitiam cenas do cotidiano, como operários saindo de uma fábrica, um trem em movimento, ou um malabarista em ação. Esse cinema é pouco metafórico, sem estilo e recursos para transmitir à intuição do movimento do real. Porém o cinema de hoje é rico em técnicas narrativas, e é uma ferramenta poderosa para transmitir ideias, despertar intuições e enriquecer o intelecto.

Bergson utilizou o cinema para ilustrar o funcionamento do pensamento conduzido e estruturado a partir de ilusões, ao mesmo tempo que concebe a arte e a metáfora como as ferramentas para transmitir a ideia da duração e consequentemente despertar a intuição, via que torna possível superar as ilusões geradas pela inteligência. O cinema é hoje a arte que mais gira recursos e movimenta as pessoas, porém quando Bergson cunhou "o mecanismo cinematográfico do pensamento", o cinema ainda não era considerado a sétima arte, mas apenas uma tecnologia nascente, que despertava a atenção e o espanto dos observadores. A concretização do cinema como uma arte nobre demandou desenvolvimento de técnicas narrativas a partir do corte e da união do áudio com o visual. O corte transformou o cinema, e abriu 
a possibilidade de acessar planos de consciência distintos em um piscar de olhos. Portanto foi em 1907 que Bergson, segundo Gilles Deleuze, cunhou a tese injusta: o método cinematográfico do pensamento de análise do real, como sede das ilusões e dos falsos problemas que permeiam a teoria do conhecimento. Injusto pelo fato do cinema ser provavelmente a arte mais completa, e que, portanto, possui o maior potencial de transmitir a imagem da passagem e do movimento necessárias para despertar a intuição filosófica.

O cinema inicialmente era composto de fotogramas, que justapostos pelo trabalho de um mecanismo e projetados em uma tela por uma lente e uma lâmpada geravam a ilusão do movimento. Esse é processo analógico de projeção das imagens. Hoje, com o avanço ininterrupto da tecnologia, o cinema e o vídeo estão na era digital, porém o movimento aqui também é formado por imobilidades. O digital é fruto da tecnologia dos computadores, onde cada imagem, som, ou dado de informação é formado a partir da linguagem básica dos computadores, isto é, a linguagem binária de zero e um. Pela alternância de zero e um em uma sequência, o computador cria todas as cores e sons necessários para transmitir qualquer imagem ou informação. Essa linguagem de máquina é complicadíssima para a compreensão humana, pois uma sequência extensa de zeros e uns é extremamente abstrata. Desenvolvemos então linguagens intermediárias para facilitar a comunicação dos programadores com a máquina. Essas linguagens intermediárias são compostas por funções e cálculos matemáticos, loopings e outros dispositivos lógicos que comandam a sequência de informação a ser processada pelo computador. No fundo, o digital é tão geométrico e matemático quanto a própria inteligência, sendo o computador a ferramenta que mais reflete suas características fundamentais. O mecanismo cinematográfico do pensamento poderia então ser pensado como mecanismo computacional sem perda ou distorção do significado original, e estaríamos apenas atualizando a metáfora de outrora, utilizando outra tecnologia onde a geometria natural do espírito humano está presente. 


\section{Bibliografia}

Bergson, Henri. A evolução Criadora. UNESP, 2010.

—. Ensaio sobre os dados imediatos da consciência. Edições 70, 2011.

—. Matéria e memória. Martins Fontes, 2010.

—. O pensamento e o movente. Martins Fontes, 2006.

Deleuze, Gilles. Bergsonismo. Editora 34, 1999.

—. Diferença e Repetição. Graal, 2009.

Heráclito, de Éfeso. Heráclito fragmentos contextualizados. São Paulo: Odysseus Editora, 2012.

Júnior, Bento Prado. Presença e Campo transcendental. EDUSP, 1988.

Leopoldo, Franklin. Bergson: intuição e discurso filosófico. Loyola, 1994.

Tennyson, Alfred. Poemas de Alfred Tennyson. Lisboa: Saída de Emergência, 2009.

Worms, Friederic. Bergson ou os dois sentidos da vida. FAP-UNIFESP, 2011. 